\title{
NTPDase1 Modulates Smooth Muscle Contraction in Mice Bladder by Regulating Nucleotide Receptor Activation Distinctly in Male and Female
}

\author{
Romuald Brice Babou Kammoe ${ }^{1,2} \mathbb{D}$, Gilles Kauffenstein ${ }^{1,2,3} \mathbb{D}$, Julie Pelletier ${ }^{1}$, Bernard Robaye ${ }^{4}$ and \\ Jean Sévigny 1,2 ,*(D) \\ 1 Centre de Recherche du CHU de Québec, Université Laval, Québec City, QC G1V 4G2, Canada; \\ Romuald.Babou@crchudequebec.ulaval.ca (R.B.B.K.); kauffenstein@unistra.fr (G.K.); \\ Julie.Pelletier@crchudequebec.ulaval.ca (J.P.) \\ 2 Département de Microbiologie-Infectiologie et d'immunologie, Faculté de Médecine, Université Laval, \\ Québec City, QC G1V 0A6, Canada \\ 3 UMR INSERM 1260, Centre de Recherche en Biomédecine de Strasbourg, Université de Strasbourg, \\ 67084 Strasbourg, France \\ 4 Institut de Recherche Interdisciplinaire en Biologie Humaine et Moléculaire, Université Libre de Bruxelles, \\ 10 rue Adrienne Bolland, 6041 Gosselies, Belgium; Bernard.Robaye@ulb.be \\ * Correspondence: jean.sevigny@crchudequebec.ulaval.ca; Tel.: +1-418-525-4444 (ext. 46319); Fax: \\ $+1-418-654-2765$
}

check for updates

Citation: Babou Kammoe, R.B.; Kauffenstein, G.; Pelletier, J.; Robaye, B.; Sévigny, J. NTPDase1 Modulates Smooth Muscle Contraction in Mice Bladder by Regulating Nucleotide Receptor Activation Distinctly in Male and Female. Biomolecules 2021, 11, 147. https://doi.org/10.3390/ biom11020147

Academic Editor: Vladimir N. Uversky

Received: 23 December 2020

Accepted: 20 January 2021

Published: 23 January 2021

Publisher's Note: MDPI stays neutral with regard to jurisdictional claims in published maps and institutional affiliations.

Copyright: (C) 2021 by the authors. Licensee MDPI, Basel, Switzerland. This article is an open access article distributed under the terms and conditions of the Creative Commons Attribution (CC BY) license (https:/ / creativecommons.org/licenses/by/ $4.0 /)$.

\begin{abstract}
Nucleotides released by smooth muscle cells (SMCs) and by innervating nerve terminals activate specific P2 receptors and modulate bladder contraction. We hypothesized that cell surface enzymes regulate SMC contraction in mice bladder by controlling the concentration of nucleotides. We showed by immunohistochemistry, enzymatic histochemistry, and biochemical activities that nucleoside triphosphate diphosphohydrolase-1 (NTPDase1) and ecto-5'-nucleotidase were the major ectonucleotidases expressed by SMCs in the bladder. RT-qPCR revealed that, among the nucleotide receptors, there was higher expression of $\mathrm{P} 2 \mathrm{X} 1, \mathrm{P}_{2} \mathrm{Y}_{1}$, and $\mathrm{P}_{2} \mathrm{Y}_{6}$ receptors. Ex vivo, nucleotides induced a more potent contraction of bladder strips isolated from NTPDase 1 deficient $\left(\right.$ Entpd1 $1^{-/-}$) mice compared to wild type controls. The strongest responses were obtained with uridine $5^{\prime}$ triphosphate (UTP) and uridine $5^{\prime}$-diphosphate (UDP), suggesting the involvement of $\mathrm{P}_{2} \mathrm{Y}_{6}$ receptors, which was confirmed with $P 2 r y 6^{-I-}$ bladder strips. Interestingly, this response was reduced in female bladders. Our results also suggest the participation of $\mathrm{P} 2 \mathrm{X} 1, \mathrm{P}_{2} \mathrm{Y}_{2}$ and/or $\mathrm{P}_{2} \mathrm{Y}_{4}$, and $\mathrm{P} 2 \mathrm{Y}_{12}$ in these contractions. A reduced response to the thromboxane analogue U46619 was also observed in wild type, Entpd1 ${ }^{-1-}$, and $P 2 r y 6^{-I-}$ female bladders showing another difference due to sex. In summary, NTPDase1 modulates the activation of nucleotide receptors in mouse bladder SMCs, and contractions induced by $\mathrm{P}_{2} \mathrm{Y}_{6}$ receptor activation were weaker in female bladders.
\end{abstract}

Keywords: NTPDase1; extracellular nucleotides; bladder; smooth muscle cells; contraction; $\mathrm{P}_{2} \mathrm{Y}_{6}$ receptor; sex

\section{Introduction}

In addition to their role in cell metabolism, nucleotides and nucleosides are extracellular mediators that activate biological responses such as smooth muscle cell contraction [1]. Cells subjected to activation or mechanical stress release nucleotides in large quantities [2,3]. Virtually all cells are capable of releasing nucleotides in a controlled manner $[4,5]$. The mechanisms of nucleotide release have been the subject of intense research activities which revealed distinct pathways of release. For example, while activated platelets and neurons release nucleotides by exocytosis [6], nucleotide efflux occurs in neutrophils and T cells via pannexin-1 hemi-channels $[7,8]$. Certain cells also release nucleotides in a constitutive manner $[9,10]$. Smooth muscle cells (SMCs) from the walls of blood vessels can release up 
to $60 \%$ of their nucleotide content without affecting their viability [11]. This release occurs in response to stimulation by norepinephrine or by adenosine $5^{\prime}$-triphosphate (ATP) itself as when released by sympathetic nerve endings [11]. Prolonged exercise and hypoxia also trigger the release of nucleotides by cardiac and skeletal myocytes [12,13].

Once released, nucleotides activate P2X ionotropic receptors (P2X1-7) and P2Y metabotropic receptors (P2 $\mathrm{Y}_{1,2,4,6,11-14}$ [4] coupled to $\mathrm{G}$ proteins, which are expressed in a ubiquitous manner [14,15]. The P2 receptor subtypes differ from one another according to their selectivity towards nucleotides [16-18]. While all P2X receptors are activated by ATP, $\mathrm{P} \mathrm{Y}_{1}, \mathrm{P}_{2} \mathrm{Y}_{12}$, and $\mathrm{P} 2 \mathrm{Y}_{13}$ are activated by adenosine $5^{\prime}$-diphosphate (ADP), $\mathrm{P}_{2} \mathrm{Y}_{2}$ by ATP and uridine $5^{\prime}$-triphosphate (UTP), $\mathrm{P} \mathrm{Y}_{4}$ by UTP, $\mathrm{P}_{2} \mathrm{Y}_{6}$ by uridine $5^{\prime}$-diphosphate (UDP) (also by UTP in the mouse [19]), P2 $_{11}$ by ATP $>$ ADP, and P2 $\mathrm{Y}_{14}$ by UDP-glucose [20]. In addition, adenosine, which results from the complete dephosphorization of ATP and ADP by ectonucleotidases, activates $P 1$ receptors, which are divided into four subtypes: $A_{1}, A_{2 A}, A_{2 B}$, and $A_{3}$ [21]. These receptors are widely distributed and their activation modulates a large number of biological processes, including the contraction of vascular smooth muscles [22]. ATP released as a co-transmitter with norepinephrine from sympathetic nerve endings causes calcium mobilization in vascular SMCs and vasoconstriction [23]. In contrast, activation of the adenosine $\mathrm{A}_{2 \mathrm{~A}}$ receptor in these cells causes coronary vasodilation [24].

Nucleotide-induced responses can be modulated by cell surface enzymes, including members of the ecto-nucleoside triphosphate diphosphohydrolase (E-NTPDases) family [25]. These enzymes convert nucleosides tri- (ATP and UTP) and diphosphate (ADP and UDP) to their monophosphate derivative (adenosine $5^{\prime}$-monophosphate (AMP) and uridine $5^{\prime}$-monophosphate (UMP)) [26]. Hydrolysis thus terminates the nucleotide signal but can also allow the transient activation of P2 receptors activated by ADP or UDP [26]. Then, AMP is further hydrolyzed by ecto- $5^{\prime}$-nucleotidase to generate adenosine, the ligand of $\mathrm{P} 1$ receptors $[25,27]$. Thus, these enzymes have the ability to control the relative concentrations of each nucleotide and nucleoside and, consequently, regulate the activation of P2 and P1 receptors and their effects [9]. The E-NTPDase family consists of eight members (NTPDase1-8), which have one or two transmembrane domains [28]. While NTPDase1, -2, -3 , and -8 are linked to the plasma membrane with their active site facing the extracellular compartment, NTPDase4, $-5,-6$, and -7 are mainly located in the membrane of intracellular organelles [25]. Thus NTPDase1, $-2,-3$, and -8 can, in theory, regulate the activation of P2 receptors $[26,29,30]$. Importantly, each ectonucleotidase has distinct biochemical properties and affinity for the substrate, thus allowing fine regulation of the levels and effects of the nucleotides on their receptors [26]. Indeed, NTPDase1 effectively hydrolyzes ATP and ADP by producing AMP, NTPDase2 primarily hydrolyzes ATP and produces an accumulation of ADP while NTPDase3 and -8 act in an intermediate way between the two first cited [26].

Growing evidence suggests that extracellular nucleotides and NTPDase1 are involved in modulating the contraction of SMCs. We demonstrated that NTPDase1 is the ectonucleotidase responsible for the major part of the hydrolysis of nucleotides at the surface of vascular SMCs [19], its absence leading to a powerful contraction to UTP and UDP nucleotides via the activation of the ${\mathrm{P} 2 \mathrm{Y}_{6}}_{6}$ receptor [19]. We also observed that NTPDase1 is expressed in SMCs of the intestine and vas deferens [31,32]. We reported that NTPDase1 was essential for maintaining expression and function of the P2X1 receptor in murine vas deferens and that its absence in Entpd $1^{-/-}$mice resulted in P2X1 desensitization, which hampered the contraction of the vas deferens resulting in reduced ejaculation and fertility [32].

The goal of the present work was to study the role of the dominant ectonucleotidase in mice bladder and to test whether this enzyme can modulate the contraction of this tissue. We observed that NTPDase1 was the major enzyme responsible for the hydrolysis of nucleotides at the surface of SMCs and that its absence resulted in an increased response to nucleotides which was different between male and female. 


\section{Materials and Methods}

\subsection{Materials}

Paraformaldehyde (PFA), PMSF (phenylmethylsulfonyl fluoride), Tris-base, maleic acid, lead nitrate $\left(\mathrm{Pb}\left(\mathrm{NO}_{3}\right)_{2}\right)$, manganese chloride $\left(\mathrm{MnCl}_{2}\right)$, potassium chloride $(\mathrm{KCl})$, ammonium sulfite $\left(\left(\mathrm{NH}_{4}\right)_{2} \mathrm{SO}_{3}\right.$, magnesium sulfate $\left(\mathrm{MgSO}_{4}\right)$, 5-hydroxytryptamine (5HT), potato apyrase grade 7 , adenosine $5^{\prime}$-triphosphate (ATP), adenosine $5^{\prime}$-diphosphate (ADP), uridine $5^{\prime}$-triphosphate (UTP), uridine 5'-diphosphate (UDP), and adenosine $5^{\prime}$ monophospahe (AMP) were purchased from Sigma-Aldrich (Oakville, ON, Canada). Thromboxane A2 analog (U46619) was purchased from Cayman Chemical (Ann Arbor, MI, USA). Sucrose and sodium chloride ( $\mathrm{NaCl}$ ) were obtained from Wisent (St Bruno, Canada). Calcium chloride $\left(\mathrm{CaCl}_{2}\right)$ and dextrose were purchased from Fisher Scientific (Waltham, MT, USA). $\mathrm{KH}_{2} \mathrm{PO}_{4}$ and sodium bicarbonate $\left(\mathrm{NaHCO}_{3}\right)$ were obtained from EMD Millipore (Mississauga, ON, Canada). Carbachol was purchased from Tocris Biosciences (Minneapolis, MN, USA). Cytokeratin 7 (Krt7) and smooth muscle myosin heavy chain 11 (Myh11) were purchased from Qiagen (Toronto, ON, Canada). Trizol was obtained from Invitrogen (Carlsbad, CA, United States). N',N'-dimethyl-N-[4-[(E)-(3-methyl-1,3-benzothiazol-2ylidene)methyl]-1-phenylquinolin-1-ium-2-yl]-N-propylpropane-1,3-diamine (SYBR Green) and DNAseI were from Roche Diagnostics (Indianapolis, IN, United States). Oligo (dt) $)_{18}$ was obtained from Fisher Scientific (Ottawa, ON, Canada). Antibodies against mouse NTPDase1 (mN1-2 ${ }_{\mathrm{C}}$ [33], mouse NTPDase2 (mN2-36 $)$ [34], mouse NTPDase3 (mN3-3c) [33], mouse NTPDase8 $\left(\mathrm{mN8}-3_{\mathrm{C}}\right)$ [35], and rat ecto- ${ }^{\prime}$-nucleotidase $\left(\mathrm{rNu}-9_{\mathrm{L}}\right)$ [36] were from http:/ / ectonucleotidases-ab.com/.

\subsection{Animals}

All experiments were conducted in accordance with the guidelines of the Canadian Council on Animal Care, and protocols were approved by the Animal Care Committees of Université Laval. The protocol number 14-181 originally approved in February 2015 was renewed yearly and was updated to 19-010 in February 2019. Adult male and female C57BL/ 6 mice 12 to 16 weeks old (Charles River, Pointe-Claire, QC, Canada) were used as controls (65 wild type (WT) males and 44 WT females). NTPDase1-deficient (Entpd1 ${ }^{-/-}$) mice were provided by Dr. S. C. Robson (BIDMC, HMS, Boston, MA) [30]. Entpd1 ${ }^{-/-}$ mice, originally from the $129 \mathrm{SVJ} \times \mathrm{C} 57 \mathrm{BL} / 6$ background, were backcrossed 14 generations onto the C57BL/ 6 background. $\mathrm{P}^{2} \mathrm{Y}_{6}$-deficient $\left({\mathrm{P} 2 r y 6^{-/}}^{-}\right)$mice obtained from B. Robaye (Université Libre de Bruxelles, Belgium) [37] were backcrossed 12 times with C57BL/6 mice from Charles River. A few backcrosses with wild type (WT) females were performed to ascertain that the mitochondrial DNA was the same in all mutant and control mice. Heterozygotes were then mated to obtained homozygote mice to generate a colony of both $P 2 r y 6^{-/-}$and Entpd1 $1^{-/-}$mice. In our experiments, we used 46 Entpd1 ${ }^{-/-}$males,

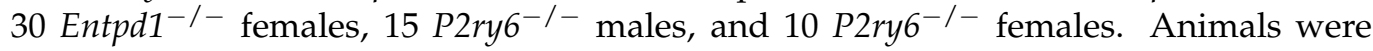
maintained in a specific pathogen-free environment in a temperature-controlled room $\left(21^{\circ} \mathrm{C}\right)$ on a 12-h/12-h light and dark cycle and given unrestricted access to standard diet and tap water (or specified drinking solution).

\subsection{Enzyme Histochemistry}

Freshly dissected bladders from 16-week-old mice (3 WT males, 3 WT females, 3 Entpd1 $1^{-/-}$males, and 3 Entpd1 ${ }^{-/-}$females), sacrificed following isoflurane anesthesia, were embedded in optimal cutting temperature (OCT) freezing medium (Tissue-Tek, Sakura Finetek, Torrance, CA, USA), snap-frozen in isopentane in dry ice, and stored at $-80^{\circ} \mathrm{C}$. Bladder sections $(6 \mu \mathrm{m})$ obtained using a 2800 Frigocut-E Cryostat (Reicher-Jung, Leica Instruments $\mathrm{GmbH}$, Deutschland, Germany) were prepared and routinely fixed in $10 \%$ phosphate-buffered formalin mixed with cold acetone (Fisher Scientific, Ottawa, ON, Canada) before further processing. Ectonucleotidase activities in bladder sections were localized using the Wachstein-Meisel lead phosphate precipitation method, as described [38]. Briefly, fixed tissue sections were preincubated for $30 \mathrm{~min}$ at $25^{\circ} \mathrm{C}$ in Tris-maleate buffer 
( $2 \mathrm{mM} \mathrm{CaCl}_{2}, 250 \mathrm{mM}$ sucrose, $50 \mathrm{mM}$ Tris-maleate, $\mathrm{pH}$ 7.4). Enzymatic reaction for the hydrolysis of $100 \mu \mathrm{M}$ nucleotides was performed for $40 \mathrm{~min}$ at $37^{\circ} \mathrm{C}$ in the same buffer supplemented with $5 \mathrm{mM} \mathrm{MnCl}_{2}, 2 \mathrm{mM} \mathrm{Pb}\left(\mathrm{NO}_{3}\right)_{2}$, and 3\% dextran T250 (wt/vol). For control experiments, substrate was omitted. Reaction products were revealed by incubation of tissue sections with $1 \%\left(\mathrm{NH}_{4}\right)_{2} \mathrm{SO}_{3}$ ( vol/vol) for $1 \mathrm{~min}$. Sections were counterstained with aqueous hematoxylin, mounted in Mowiol mounting medium, and photographed under a microscope (model BX51, Olympus).

\subsection{Immunohistochemistry}

Sixteen-week-old mice (3 WT males, 3 WT females, 3 Entpd1 ${ }^{-/-}$males, and 3 Entpd1 ${ }^{-1-}$ females) were sacrificed following isoflurane anesthesia. Bladder samples were excised, fixed in $4 \%$ paraformaldehyde for $4 \mathrm{~h}$, immersed in sucrose overnight, and included in OCT freezing medium, sectioned, and processed for staining as previously described [33]. Briefly, 6 $\mu \mathrm{m}$ tissue sections were incubated overnight at $4{ }^{\circ} \mathrm{C}$ with the primary antibodies guinea pig anti-mouse NTPDase1 (mN1-2 $)$ [33], rabbit anti-mouse NTPDase2 (mN2-36 $)$ [34], guinea pig anti-mouse NTPDase3 $\left(\mathrm{mN} 3-3_{C}\right)$ [33], guinea pig anti-mouse NTPDase8 $\left(\mathrm{mN} 8-3_{\mathrm{C}}\right)$ [35] or rabbit anti-rat ecto-5'-nucleotidase $\left(\mathrm{rNu}^{\prime}-9_{\mathrm{L}}\right)$ [36], and then with biotinylated goat anti-guinea pig or anti-rabbit secondary antibodies, accordingly, at $25^{\circ} \mathrm{C}$. Pre-immune sera were routinely included as controls. Sections were counterstained with aqueous hematoxylin, mounted in Mowiol mounting medium, and photographed under a microscope (model BX51, Olympus).

\subsection{Nucleotidase Activity Measurement}

Tissues from 16-week-old mice (11 WT males, 7 Entpd1 ${ }^{-/-}$males and 4 WT females), were homogenized with a polytron in the following buffer: $95 \mathrm{mM} \mathrm{NaCl}, 0.1 \mathrm{mM}$ PMSF, and $45 \mathrm{mM}$ Tris, $\mathrm{pH}$ 7.6. The homogenates were centrifuged at $3000 \mathrm{rpm}$ for $5 \mathrm{~min}$ using a Mikro 200R centrifuge (Hettich Company, MT, USA) and the resulting supernatants were used for activity measurements. The enzyme activity of protein extract was measured at $37^{\circ} \mathrm{C}$ in $1 \mathrm{~mL}$ of the reaction buffer constituted of $5 \mathrm{mM} \mathrm{CaCl}_{2}, 80 \mathrm{mM}$ Tris buffer $\mathrm{pH} 7.4$ as described previously $[39,40]$. Briefly, $10 \mu$ lof protein at the appropriate dilution was added to the reaction buffer and was incubated for $3 \mathrm{~min}$ at $37^{\circ} \mathrm{C}$. The reaction was started by the addition of $0.5 \mathrm{mM}$ substrate (ATP, ADP, UTP, UDP, or AMP). The reaction was stopped after $15 \mathrm{~min}$ by the addition of $250 \mu \mathrm{l}$ of malachite green reagent, and the liberated inorganic phosphate $(\mathrm{Pi})$ was measured at $630 \mathrm{~nm}$ according to the methodology described by Baykov et al. (1988) [40]. The results were expressed as nmoles $\mathrm{Pi} / \mathrm{min} / \mathrm{mg}$ protein. All experiments were performed in triplicate. For control or blank experiments, the diluted protein $(10 \mu \mathrm{l})$ was added after stopping the reaction with malachite green.

\subsection{Quantitative Real-Time PCR (RT-qPCR)}

RT-qPCR was performed on bladder smooth muscle cell layers from 16-week-old mice and consisted of three independent experiments, each with bladders pooled from three mice, for a total of $9 \mathrm{WT}$ male, 9 WT female, 9 Entpd $1^{-/-}$male, and 9 Entpd1 ${ }^{-/}$female mice. For this purpose, mice were anesthetized by isoflurane inhalation and perfused with phosphate-buffered saline (PBS) following the method described by Lu et al. (2019) [41]. Briefly, approximately $24 \mathrm{~mL}$ of PBS was injected in the left ventricle of mouse heart while the right atrium was cut. After the lungs and liver were completely emptied of blood, the bladder was removed, and the smooth muscle layer was separated from the mucosa (epithelium and lamina propria) under a magnifying glass using pliers. RNA was isolated using the Trizol method according to the manufacturer's recommendation (Invitrogen). Briefly, total RNA from male and female mice bladder smooth muscle layer was extracted with Trizol then quantified with a Biodrop spectrophotometer. The cDNA was synthesized with SuperScript III from $1 \mu \mathrm{g}$ of total RNA with oligo $(\mathrm{dT})_{18}$ as the primer, according to the instructions of the manufacturer (Invitrogen, Carlsbad, CA, USA). Primers specific for the ectonucleotidases (Entpdl, Entpd2, Entpd3, and Entpd8), ecto-5'-nucleotidase (Nt5e), P2X (P2rx1-7), P2Y (P2ry1, P2ry2, P2ry4, P2ry6, and P2ry12-14) and P1 receptors (Adora 1, 
Adora2a, Adora2b, and Adora3) were either designed by us and synthetized by Invitrogen (Carlsbad, CA, USA) or purchased from Qiagen (Toronto, ON, Canada), as detailed in Table 1. Prior to RT-qPCR of target genes, bladder smooth muscle layer purity was verified by quantifying Krt7 and Myh11. For quantitative PCR, equal amounts of cDNA were run in duplicate and amplified in a final volume of $10 \mu \mathrm{L}$ containing $9 \mu \mathrm{L}$ of a mixture of $2 \mathrm{X}$ FastStart Universal SYBR Green Master Mix (Roche Diagnostics, Indianapolis, IN, USA), specific primers and RNase-DNase free water, and $1 \mu \mathrm{l}$ of target cDNA. The mixture was incubated at $50{ }^{\circ} \mathrm{C}$ for $2 \mathrm{~min}$, at $95^{\circ} \mathrm{C}$ for $10 \mathrm{~min}$, and then cycled 40 times at $95^{\circ} \mathrm{C}$ for $15 \mathrm{~s}$ and at $60^{\circ} \mathrm{C}$ for $1 \mathrm{~min}$ using the Applied Biosystems Prism 7900 Sequence Detector. For the negative controls, water was used as template. Standard curves were used to determine mRNA transcript copy number in individual reactions. Glyceraldehyde 3-phosphate dehydrogenase (Gapdh) or actin beta (Actb) was used as reference genes to normalize RNA quantities between samples.

\subsection{Measurement of Bladder Strips Contraction}

Mice were sacrificed by $\mathrm{CO}_{2}$ inhalation, and their bladders were excised and placed in ice-cold physiological salt solution containing Krebs buffer $118 \mathrm{mM} \mathrm{NaCl}, 4.7 \mathrm{mM}$ $\mathrm{KCl}, 1.9 \mathrm{mM} \mathrm{CaCl}_{2}, 1.2 \mathrm{mM} \mathrm{KH}_{2} \mathrm{PO}_{4}, 1.2 \mathrm{mM} \mathrm{MgSO}$, $25 \mathrm{mM} \mathrm{NaHCO}_{3}$, and $11 \mathrm{mM}$ dextrose (D-glucose). Two strips of approximately $4 \mathrm{~mm}$ long and $3 \mathrm{~mm}$ wide were prepared and mounted on a $5 \mathrm{~mL}$ vertical organ bath system connected to a Haake S3 heated circulating water bath (Thermo Scientific, Newington, NH, USA) and to an isometric transducer (Harvard Apparatus, Cambridge, MT, USA). Tissue contraction was recorded by a LKB Bromma 2210 recorder (Kipp and Zonen, Delft, Holland). The system was continuously bubbled with $95 \% \mathrm{O}_{2}$ and $5 \% \mathrm{CO}_{2}$. Bladders were set to a $1 \mathrm{~g}$ tension and left to equilibrate for $90 \mathrm{~min}$. After equilibrating contraction with $10 \mu \mathrm{M}$ carbachol, stimulation with nucleotides (ATP, ADP, UTP or UDP at $100 \mu \mathrm{M}$ ) or with 5-hydroxytryptamine (5HT) and the thromboxane analog U46619 as controls were performed. After recording each contraction for $5 \mathrm{~min}$, the system was washed and was rebalanced for $30 \mathrm{~min}$ before the next stimulation. Where indicated apyrase at a concentration of $2 \mathrm{U} / \mathrm{mL}$, or the same amount of boiled apyrase, were added to the strips $40 \mathrm{~min}$ before stimulation with the indicated nucleotides. For contraction experiments involving WT and Entpd1 ${ }^{-/}$mice, 12-week-old mice (20 WT males, 20 Entpd1 ${ }^{-/-}$males, $15 \mathrm{WT}$ females and 15 Entpd1 ${ }^{-/-}$

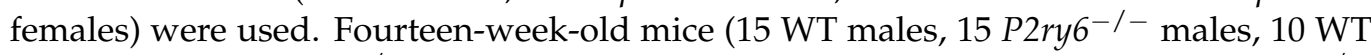
females and $10 \mathrm{P}^{\mathrm{ry}} \mathrm{G}^{-/-}$females) were used for experiments with WT and $P 2 \mathrm{ry} 6^{-/-}$ mice. For apyrase experiments, 12 -week-old mice (4 WT males and 4 Entpd1 ${ }^{-/-}$males) were used.

\subsection{Statistical Analysis}

Results are expressed as mean \pm standard error of mean (SEM). The statistical differences between mean values were assessed by two-way ANOVA followed by Tukey post-test for multiple comparisons. Statistical analysis was performed using GraphPad, Prism V7.0 (GraphPad Software San Diego, CA, USA). A value of $p<0.05$ was considered statistically significant. 
Table 1. qRT-PCR primers.

\begin{tabular}{|c|c|c|c|}
\hline Gene & Forward Primer & Reverse Primer & Amplicon (bp) \\
\hline$K r t 7$ & Qiagen & Qiagen & 134 \\
\hline Myh11 & Qiagen & Qiagen & 112 \\
\hline Gapdh & $\begin{array}{l}\text { CCA TCA CCA TCT } \\
\text { TCC AGG AG }\end{array}$ & $\begin{array}{l}\text { GTG GTT CAC ACC } \\
\text { CAT CAC AA }\end{array}$ & 194 \\
\hline$A c t b$ & $\begin{array}{c}\text { GGC TGT ATT CCC } \\
\text { CTC CAT CG }\end{array}$ & $\begin{array}{c}\text { CCA GTT GGT AAC } \\
\text { AAT GCC ATG T }\end{array}$ & 154 \\
\hline Entpdl & $\begin{array}{c}\text { AGC TGC CCC TTA } \\
\text { TGG AAG AT }\end{array}$ & $\begin{array}{c}\text { TCA GTC CCA CAG } \\
\text { CAA TCA AA }\end{array}$ & 123 \\
\hline Entpd2 & $\begin{array}{c}\text { TTC CTG GGA TGT } \\
\text { CAG GTC TC }\end{array}$ & $\begin{array}{c}\text { GTC TCT GGT GCT } \\
\text { TGC CTT TC }\end{array}$ & 132 \\
\hline Entpd3 & $\begin{array}{c}\text { ACC TGT CCC GTG } \\
\text { CTT AAA TG }\end{array}$ & $\begin{array}{l}\text { AGA CAG AGT GAA } \\
\text { GCC CCT GA }\end{array}$ & 183 \\
\hline Entpd8 & Qiagen & Qiagen & 146 \\
\hline Nt5e/CD73 & $\begin{array}{c}\text { CAG GAA ATC CAC } \\
\text { CTT CCA AA }\end{array}$ & $\begin{array}{c}\text { AAC CTT CAG GTA } \\
\text { GCC CAG GT }\end{array}$ & 128 \\
\hline P2ry1 & $\begin{array}{c}\text { TCG TGT CTC CAT } \\
\text { TCT GCT TG }\end{array}$ & $\begin{array}{c}\text { CGA CAG GGT TTA } \\
\text { TGC CAC TT }\end{array}$ & 218 \\
\hline P2ry 2 & $\begin{array}{c}\text { TGA CGA CTC AAG } \\
\text { ACG GAC AG }\end{array}$ & $\begin{array}{c}\text { GTC CCC TAC AGC } \\
\text { TCC CСТ AC }\end{array}$ & 108 \\
\hline P2ry4 & $\begin{array}{c}\text { AGA CGG GCC TGA } \\
\text { TGT GTA TC }\end{array}$ & $\begin{array}{c}\text { AGG TTC ACA TGC } \\
\text { CCT GTA CC }\end{array}$ & 126 \\
\hline P2ry6 & $\begin{array}{c}\text { GGT AGC GCT GGA } \\
\text { AGC TAA TG }\end{array}$ & $\begin{array}{c}\text { TTT CAA GCG ACT } \\
\text { GCT GCT AA }\end{array}$ & 308 \\
\hline P2ry12 & $\begin{array}{c}\text { GGC AGC CTT GAG } \\
\text { TGT TCT TC }\end{array}$ & $\begin{array}{c}\text { ATA ACG TGC TAC } \\
\text { CCG ACC TG }\end{array}$ & 130 \\
\hline P2ry13 & $\begin{array}{c}\text { ATA GAG AAC CGG } \\
\text { GAA CAG CA }\end{array}$ & $\begin{array}{c}\text { CAA AAC AAA GCT } \\
\text { GAT GCT CG }\end{array}$ & 115 \\
\hline P2ry14 & $\begin{array}{c}\text { TTT TGT CGT CTG } \\
\text { CTT TGT GC }\end{array}$ & $\begin{array}{c}\text { GCA GCC GAG AGT } \\
\text { AGC AGA GT }\end{array}$ & 135 \\
\hline$P 2 r x 1$ & $\begin{array}{c}\text { CAA CTG TGT GCC } \\
\text { CTT CAA TG }\end{array}$ & $\begin{array}{c}\text { GGT ACC ATT CAC } \\
\text { СТC СТC CA }\end{array}$ & 114 \\
\hline $\operatorname{Pr} 2 x 2$ & $\begin{array}{c}\text { GCT GGG CTT CAT } \\
\text { TGT AGA GC }\end{array}$ & $\begin{array}{c}\text { CCT GTC CAT GCA } \\
\text { CAA TAA CG }\end{array}$ & 281 \\
\hline$P 2 r \times 3$ & $\begin{array}{c}\text { ATT TCC TCA AAG } \\
\text { GGG CTG AT }\end{array}$ & $\begin{array}{c}\text { GTT CTG CAG CCC } \\
\text { AAG GAT AA }\end{array}$ & 204 \\
\hline$P 2 r \times 4$ & $\begin{array}{c}\text { CAC AAC GTG TCT } \\
\text { CCT GGC TA }\end{array}$ & $\begin{array}{c}\text { GCC TTT CCA AAC } \\
\text { ACG ATG AT }\end{array}$ & 125 \\
\hline$P 2 r x 6$ & $\begin{array}{c}\text { TCA CCC GCT AAC } \\
\text { CCT GTT AC }\end{array}$ & $\begin{array}{c}\text { TAG TCC CGC TGA } \\
\text { AGC TTT GT }\end{array}$ & 242 \\
\hline$P 2 r x 7$ & $\begin{array}{c}\text { AAT CGG TGT GTT } \\
\text { TCC TTT GG }\end{array}$ & $\begin{array}{c}\text { CCG GGT GAC TTT } \\
\text { GTT TGT CT }\end{array}$ & 165 \\
\hline Adora1 & $\begin{array}{l}\text { GTG ATT TGG GCT } \\
\text { GTG AAG GT }\end{array}$ & $\begin{array}{c}\text { AGT AGG TCT GTG } \\
\text { GCC CAA TG }\end{array}$ & 142 \\
\hline Adora $2 a$ & $\begin{array}{c}\text { TCA ACA GCA ACC } \\
\text { TGC AGA AC }\end{array}$ & $\begin{array}{c}\text { GGC TGA AGA TGG } \\
\text { AAC TCT GC }\end{array}$ & 186 \\
\hline Adora $2 b$ & $\begin{array}{c}\text { TCT GGC CTT TTG } \\
\text { GAG AAG AA }\end{array}$ & $\begin{array}{c}\text { TTT CCG GAA TCA } \\
\text { ATT CAA GC }\end{array}$ & 246 \\
\hline Adora3 & $\begin{array}{c}\text { TGT GGA GGG AGT } \\
\text { CTC GTC TT }\end{array}$ & $\begin{array}{c}\text { TCC TTC TGT TCC } \\
\text { CCA CAT TC }\end{array}$ & 101 \\
\hline
\end{tabular}

\section{Results}

3.1. Immunolocalization and Activity of Ectonucleotidases in Bladder SMCS

In mice bladder, NTPDase1 was localized at the surface of smooth muscle cells and in the lamina propria (Figure 1). No signal was observed in mice deficient in NTPDase1 $\left(\right.$ Entpd $\left.1^{-/}\right)$, confirming both the specificity of the antibody used against NTPDase1 and the absence of NTPDase1 in Entpd1 ${ }^{-/-}$mice. NTPDase2 was localized between smooth muscle fibers and in the lamina propria. There were no immunoreactions in the bladder 
SMCs when using antibodies to NTPDase3 and NTPDase8 (Figure 1). NTPDase3 immunolocalization was restricted to the epithelium while ecto-5'-nucleotidase was localized in the smooth muscle. A similar immunolocalization was observed for these 3 enzymes in male (A) and female (B) bladder.

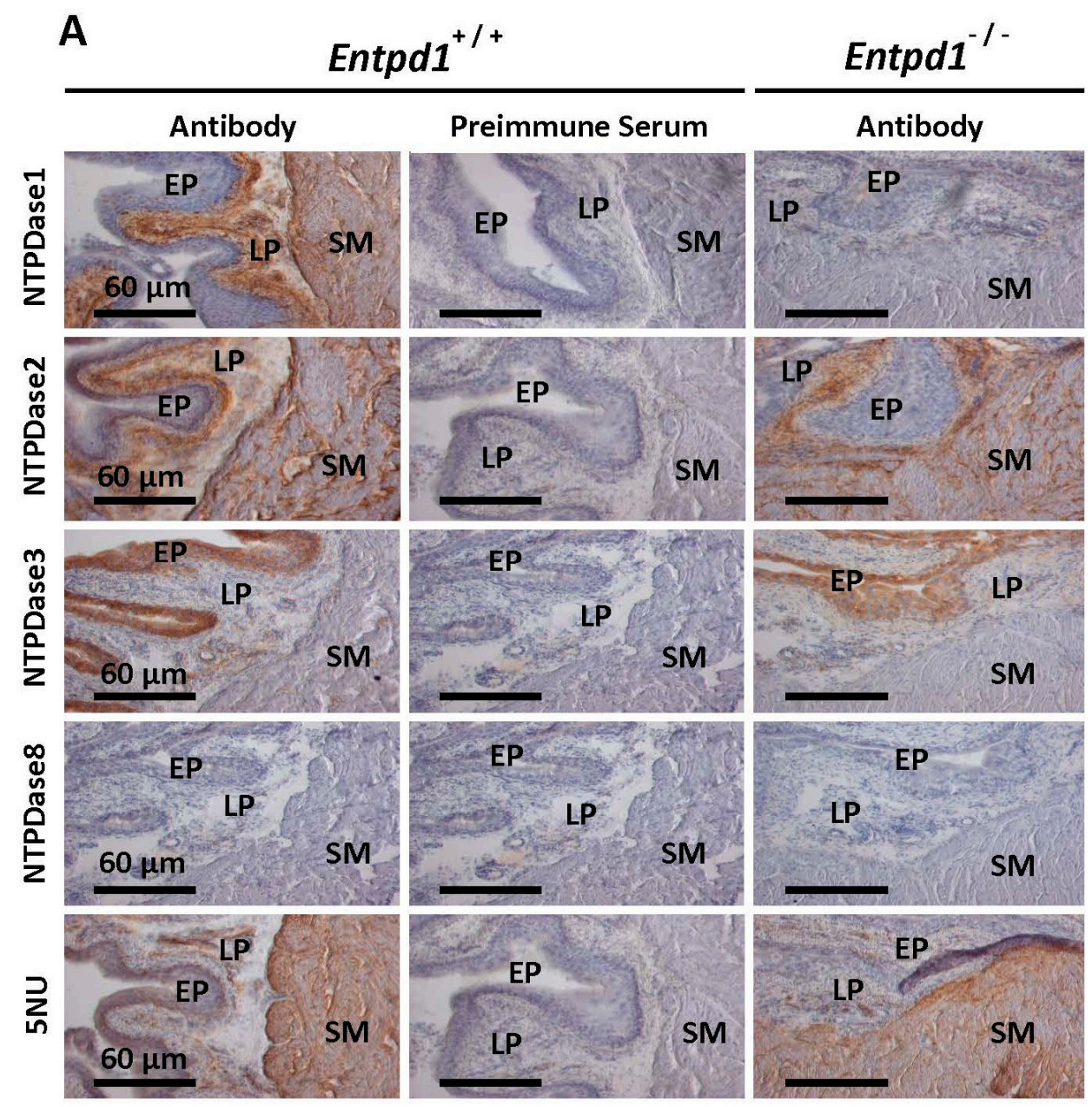

Figure 1. Cont. 


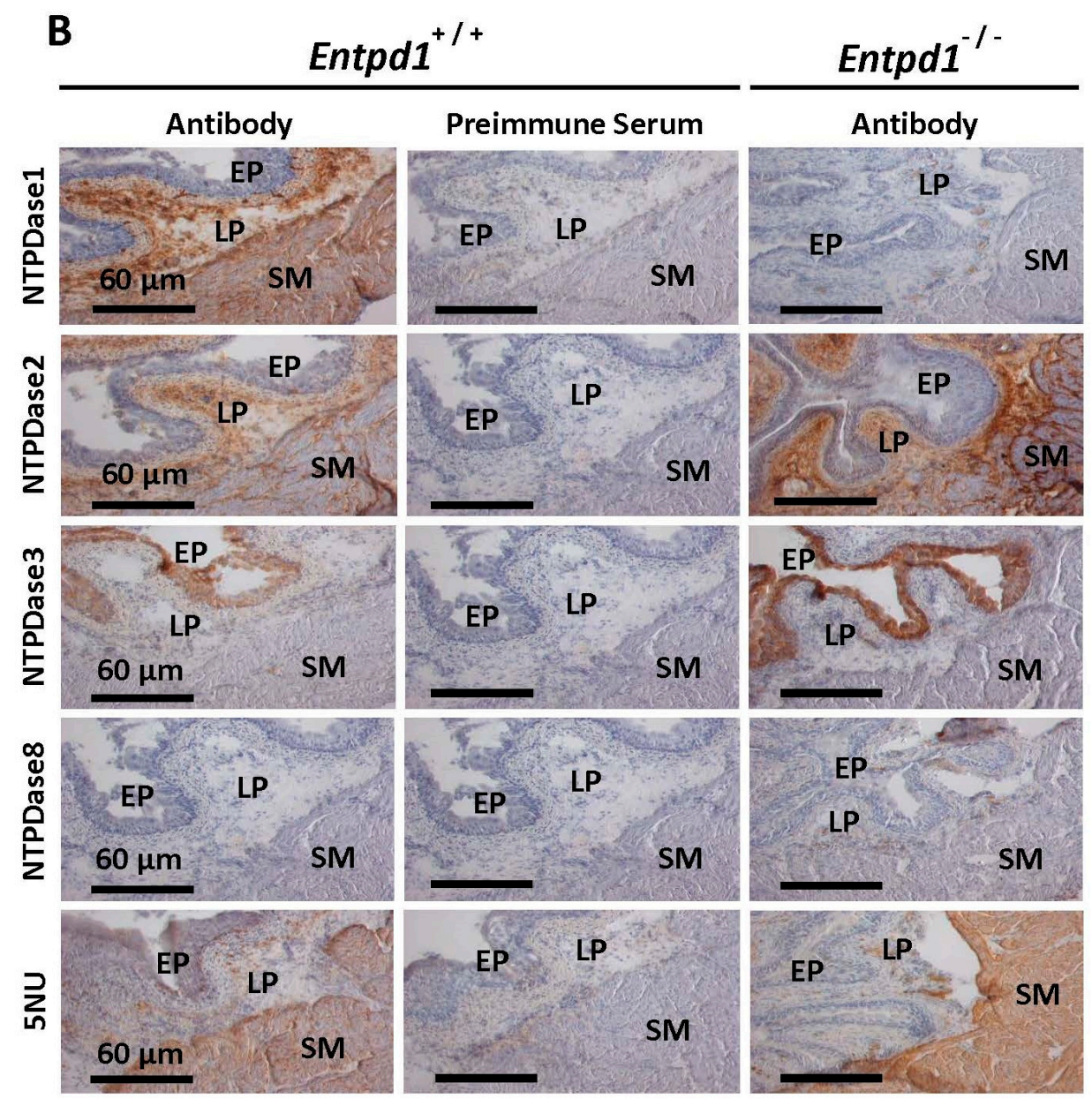

Figure 1. Immunolocalization of ectonucleotidases in male (A) and female (B) mouse bladder. SM: smooth muscle; LP: lamina propria. EP: epithelium. bar $=60 \mu \mathrm{m}$. Entpd1 $1^{+/+}$: wild type mice. Entpd1 $1^{-/-}$: NTPDase1 deficient mice. 5NU: ecto-5'-nucleotidase. Experiments were done on 3 mice of each group.

Ectonucleotidase activity in WT female bladders revealed an intense hydrolysis of nucleotides by NTPDase1 which was detected as a brown precipitate in SMCs (asterisk) of the bladder for the four P2 receptor ligands: ATP, ADP, UTP, and UDP (Figure 2). ADPase and UDPase activities were absent in female Entpd1 ${ }^{-/}$bladders. The remaining ATPase and UTPase activities between smooth muscle fibers (asterisk) in female Entpd $1^{-/-}$tissues, which is also present in WT, corresponds to NTPDase2 immunolabeling. Indeed, NTPDase2 has a low diphosphatase activity, especially when compared to NTPDase1 $[29,42]$. The activity of ecto-5'-nucleotidase which was revealed with its substrate AMP was also located at the surface of SMCs in both female WT and Entpd1 ${ }^{-/-}$ tissues. This AMPase activity correlated with ecto-5'-nucleotidase immunolabelling. The nucleotidase activities were similar in male (data not shown) as in female bladders (Figure 2). The hydrolysis of the ectonucleotidase substrates ATP, ADP, UTP, and UDP was lower in the homogenates of male bladders deficient in NTPDase1 (Figure 3A), but not for the ecto-5'-nucleotidase substrate AMP, as expected. There were no significant differences in the hydrolysis of these 5 substrates in the homogenates from male and female WT bladders (Figure 3B). 


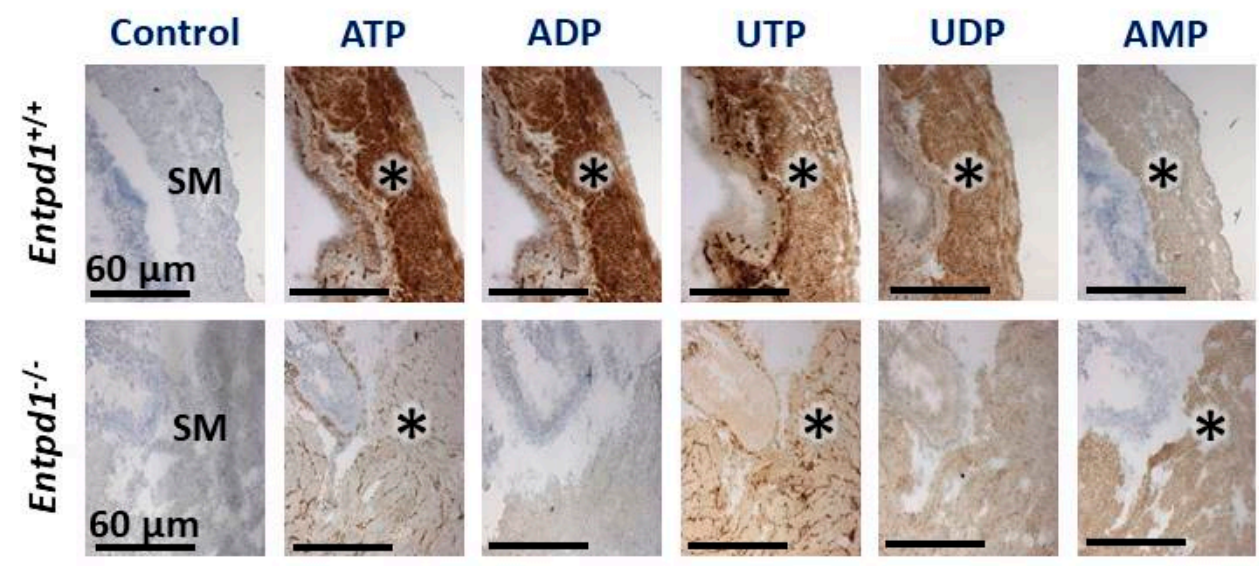

Figure 2. Comparative analysis of ectonucleotidase activity in the bladder of Entpd1 $1^{+/+}$(wild type) and Entpd1 ${ }^{-/-}$(nucleoside triphosphates diphosphohydrolase 1 (NTPDase1) deficient) female mice. $\mathrm{SM}\left(^{*}\right)$ : smooth muscle. bar $=60 \mu \mathrm{m}$. Control: no nucleotides. Adenosine $5^{\prime}$-triphosphate (ATP), adenosine $5^{\prime}$-diphosphate (ADP), uridine $5^{\prime}$-triphosphate (UTP), uridine $5^{\prime}$-diphosphate (UDP), and adenosine $5^{\prime}$-monophosphate (AMP) were used as substrate at a concentration of $100 \mu \mathrm{M}$. Experiments were done on three mice of each group.

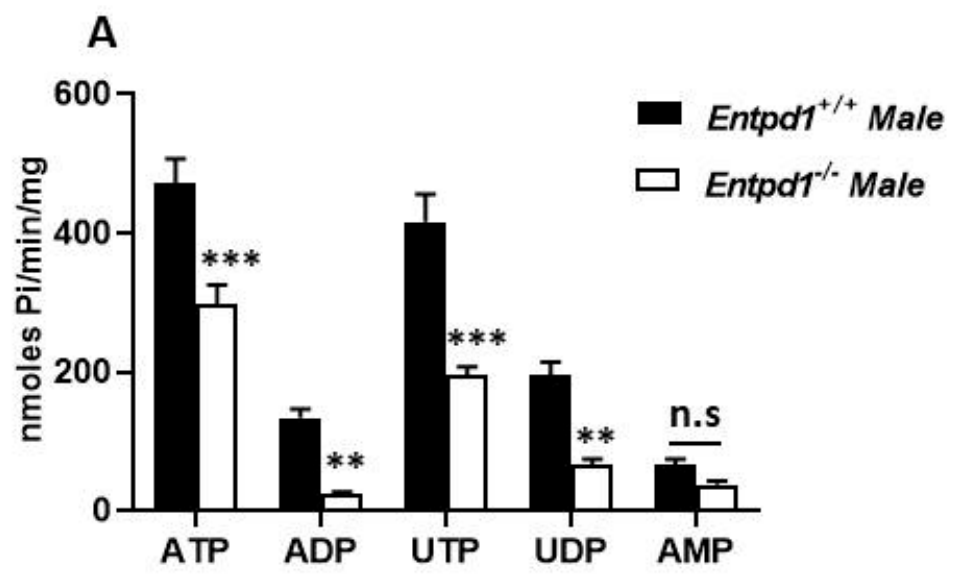

\section{B}

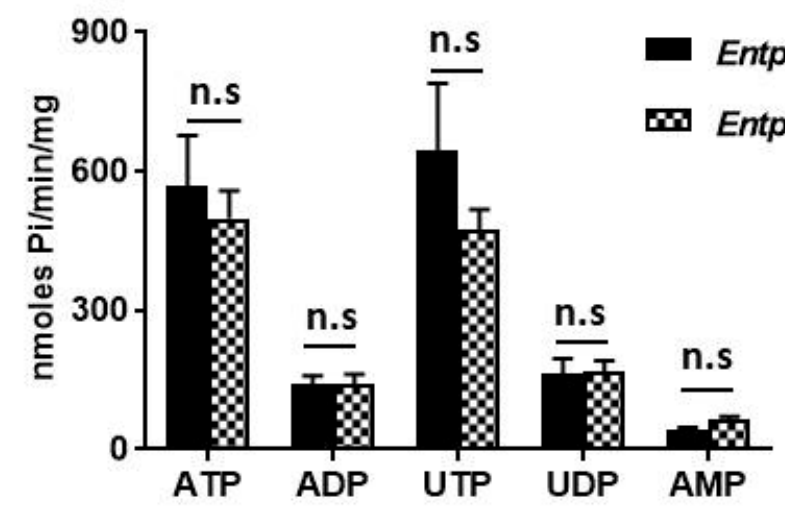

Figure 3. Hydrolysis of nucleotides in homogenates of male and female mouse bladders. Data presented are the mean \pm SEM of seven experiments with homogenates from Entpd1 $1^{+/+}$(wild type) and Entpd1 ${ }^{-/-}$(NTPDase1 deficient) male bladders (A) and four experiments with homogenates from male and female Entpd $1^{+/+}$bladders $(\mathbf{B})$, each in triplicate. Two symbols $p<0.01$, three symbols $p<0.001$. ${ }^{*}$ Hydrolysis of Entpd1 ${ }^{-/}$homogenates compared to that of wild type homogenates. n.s: not significant. ATP, ADP, UTP, UDP, and AMP were used as the substrate at a concentration of $500 \mu \mathrm{M}$. 


\subsection{Contractile Effect of Nucleotides is Increased in Entpd1 ${ }^{-/}$Bladder Strips}

We then questioned whether nucleotide could affect SMCs contraction in mouse bladder and if the dominant ectonucleotidase expressed in bladder SMCs, NTPDase1, could modulate their contractile effects. To address this question, we compared the contraction of WT bladders (Entpd1 ${ }^{+/+}$) with that of tissues deficient for NTPDase1 expression $\left(\right.$ Entpd $\left.1^{-/-}\right)$. As can be seen in Figure 4, The contraction caused by each of these four nucleotides was exacerbated in Entpd $1^{-/-}$bladders. Uracil nucleotides (UTP and UDP) produced the strongest contractions of male bladder strips. The latter contractions were significantly reduced in female bladders. The contractile effect of adenine nucleotides (ATP and ADP) was comparable in the bladders of both sexes. The non-nucleotide agonists 5-hydroxytryptamine (5HT) and the thromboxane A2 analogue U46619 activated contraction similarly in both genotypes showing that the smooth muscles in Entpd1 ${ }^{-/-}$bladders contracted normally, as in WT mice. There was a reduction in the contractile response to U46619 in strips from female bladders for both genotypes.

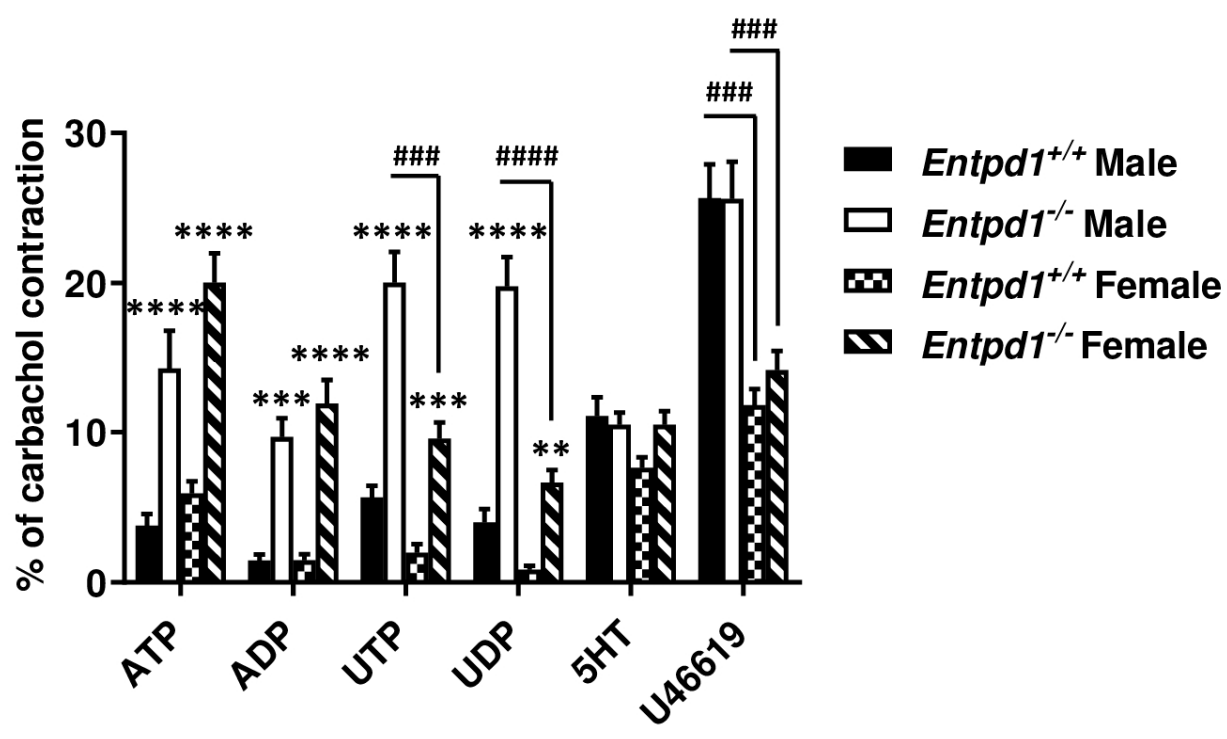

Figure 4. Contractile effect of extracellular nucleotides on male and female mouse bladder strips. Data presented are mean \pm SEM of 20 contraction experiments with Entpd1 ${ }^{+/+}$(wild type) and Entpd1 ${ }^{-/-}$ (NTPDase1 deficient) male bladders and 15 with Entpd1 ${ }^{+/+}$and Entpd1 ${ }^{-/-}$female bladders. Two symbols $p<0.01$, three symbols $p<0.001$, and four symbols $p<0.0001$. ${ }^{*}$ Contraction of Entpd1 ${ }^{-/-}$ mice compared to that of wild type strips and \# contraction of male strips compared to female strips of the same genotype. ATP, ADP, UTP, and UDP were used at a concentration of $100 \mu \mathrm{M}$, 5-hydroxytryptamine (5HT) at $10 \mu \mathrm{M}$, and U46619 at $100 \mathrm{nM}$.

3.3. mRNA Expression of Ectonucleotidases and Nucleotide Receptors in Mouse Bladder Smooth Muscle Layer

The data from Figure 4 suggest the implication of nucleotide receptors in these effects where the ectonucleotidase NTPDase1 plays a central role in the modulation of the process. We then measured the expression of these potential actors by RT-qPCR. First, we quantified Krt7 (a marker of epithelial cells) and Myh11 (a marker of SMCs) in our smooth muscle samples. As seen in Figure 6A, mRNA levels of $K r t 7$ were negligible when compared to Myh11 for both sexes and both genotypes, demonstrating that the preparation of smooth muscles is exempt of epithelial cells. It is noteworthy that we perfused the animals before sacrifice to avoid blood cell contamination. We then quantified the expression of ectonucleotidases, as well as of the nucleotide receptors and of the adenosine receptors to find the potential receptor(s) involved in the contractile response to nucleotides. Among P2Y receptors, Figure $6 \mathrm{~B}$ shows that $\mathrm{P}_{2} \mathrm{Y}_{1}$ and $\mathrm{P}_{2} \mathrm{Y}_{6}$ were the most highly expressed receptors at the mRNA levels, followed by $\mathrm{P}_{2} \mathrm{Y}_{12}, \mathrm{P}_{2} \mathrm{Y}_{4}$, and $\mathrm{P} 2 \mathrm{Y}_{2}$, respectively. A modest expression 
was measured for $\mathrm{P}_{13} \mathrm{Y}_{13}$ and $\mathrm{P}_{2} \mathrm{Y}_{14}$. Concerning P2X receptors, $\mathrm{P} 2 \mathrm{X} 1$, was the most highly expressed receptor followed by P2X7, P2X6 and P2X4, P2X3, and P2X2, in decreasing order of mRNA expression levels. No P2X5 expression was detected (Figure 6C). NTPDase1 and ecto-5'-nucleotidase showed the highest mRNA levels among the nucleotide hydrolyzing enzymes expressed followed by NTPDase2. Very low NTPDase3 expression level was measured while no NTPDase8 expression could be detected (Figure 6D). It is noteworthy to point out that NTPDase1 not only hydrolyzes the agonists of P2 receptors but, in tandem with ecto- $5^{\prime}$-nucleotidase, also generates the P1 receptor agonist. We therefore also evaluated the mRNA expression of the P1 receptors. Among these receptors, the adenosine $A 2_{B}$ receptor was the most highly expressed adenosine receptor, followed by $A_{1}, A_{2 A}$, and $A_{3}$, in decreased order of expression (Figure $6 \mathrm{E}$ ). It is noteworthy to mention that Gapdh was the most stable control in bladder smooth muscle layer for the cell markers and for the ectonucleotidases expression (Figure 6A,D) while ActB was more stable for P2Y, P2X, and P1 genes expression (Figure 6B,C,E).

\subsection{Implication of $P 2 Y_{6}$ Receptor in the Contractile Response of Bladder SMCs}

Figure 4 showed an increased contraction in Entpd1 ${ }^{-/}$- bladder SMCs for the four nucleotides tested. Among them, UTP and UDP induced the strongest contractions. As both nucleotides are agonists of $\mathrm{P}_{2} \mathrm{Y}_{6}$ receptor in mice [19], we investigated whether this receptor was involved in these effects. We therefore compared contraction of strips from WT and $\mathrm{P}^{2} \mathrm{Y}_{6} \mathrm{KO}$ bladders. While the contractile responses to ATP and ADP were similar in P2Y 6 deficient bladders of both sexes, when compared to WT bladders, the effect of the P2Y 6 agonist UDP was totally abrogated, confirming that this receptor was implicated in the response observed in Figure 4. Although the response to UTP was also reduced in strips from $P 2 r y 6^{-1-}$ bladders, it was not significantly different from WT strips (Figure 5). This implies that $\mathrm{P}_{2} \mathrm{Y}_{2}$ and/or $\mathrm{P}_{2} \mathrm{Y}_{4}$ were also responsible for part of this contraction as both receptors are also activated by UTP. Therefore, these data suggest the implication of P2Y 6 in the responses to UDP and that UTP activate contractions via P2 $\mathrm{Y}_{6}$ as well as via other P2 receptors $\left(\mathrm{P}_{2} \mathrm{Y}_{2}\right.$ and / or $\left.\mathrm{P}_{2} \mathrm{Y}_{4}\right)$. Strips from male bladders contracted significantly more in the presence of the thromboxane analogue (U46619) when compared to females in both genotypes (WT and $P 2 r Y 6^{-/-}$). 

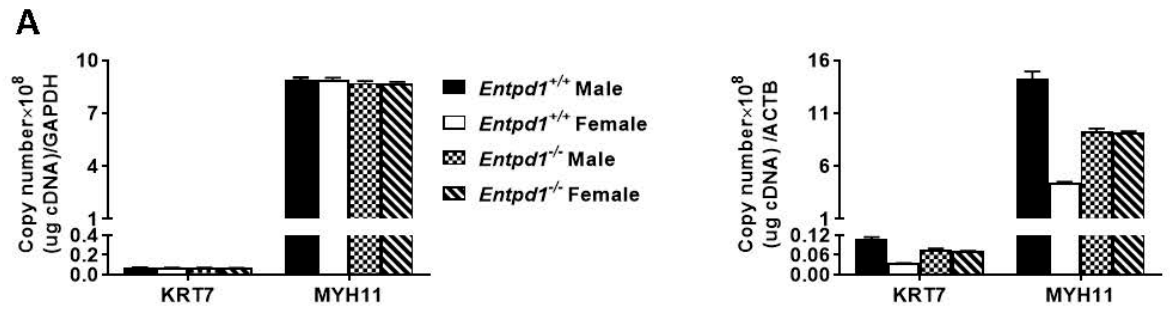

B
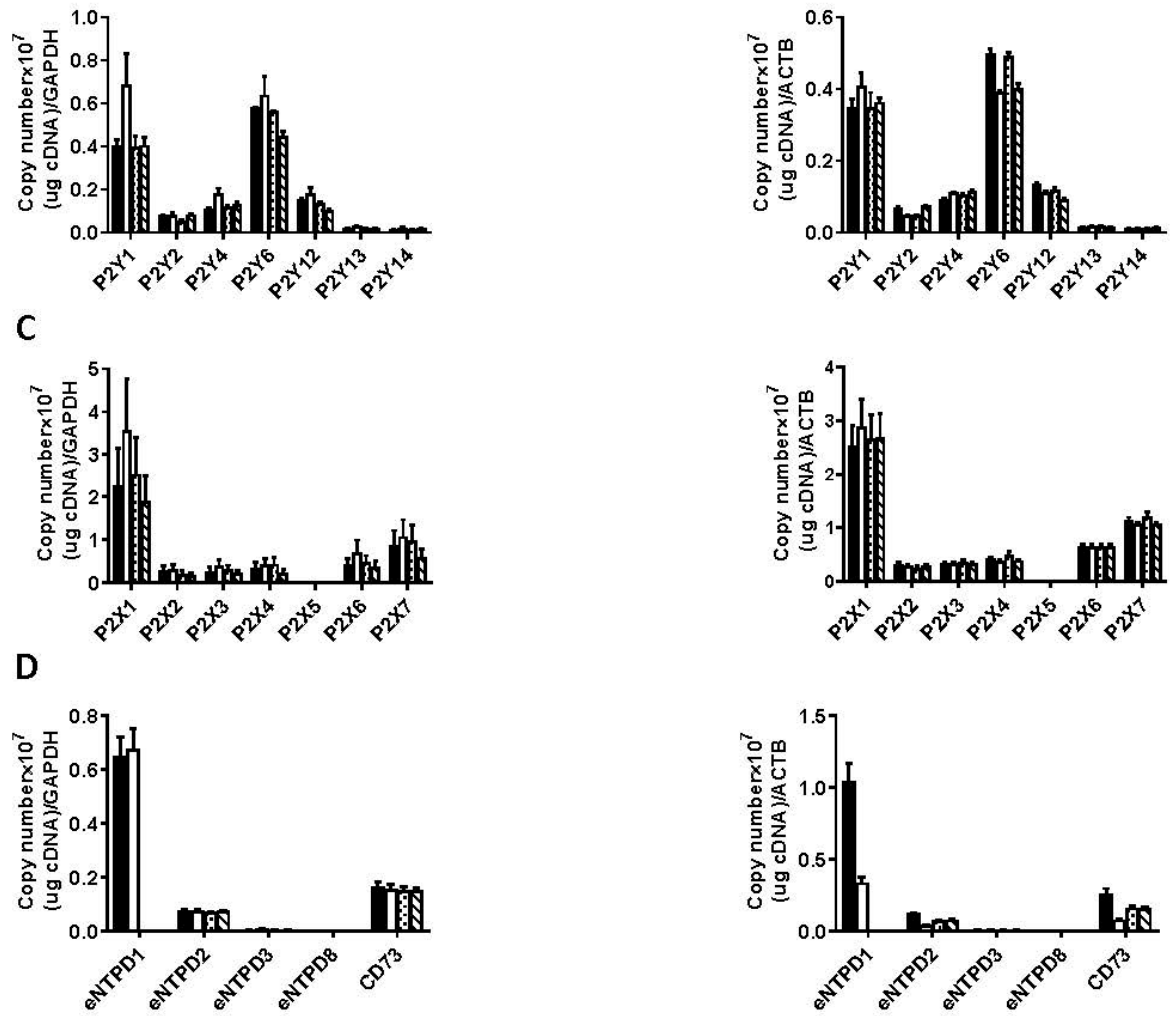

E
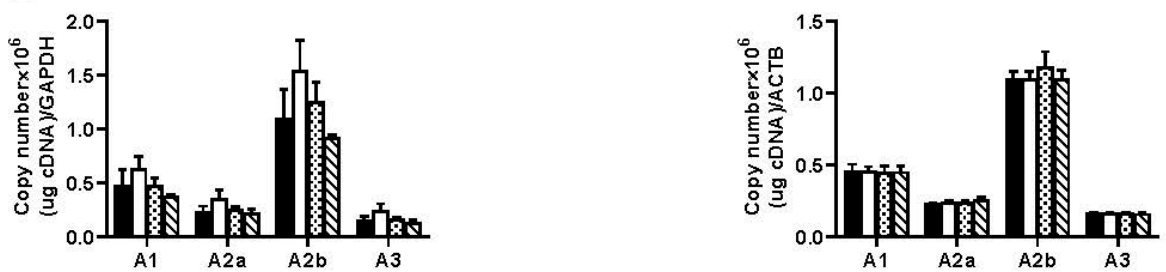

Figure 5. Gene expression profile in male and female bladder SMCs. SMCs were separated from the epithelial layer as mentioned in the "Materials and Methods" section. RNA was isolated from the SMC layer and the expression of the epithelial cell marker Krt7 and the SMC marker Myh11 (A), P2Y receptors $(B), P 2 X$ receptors $(\mathbf{C})$, ectonucleotidases $(\mathbf{D})$, and P1 receptors $($ E) were quantified by RT-qPCR. Data are normalized to GAPDH (glyceraldehyde 3-phosphate dehydrogenase; left panels) and ACTB (actin beta; right panels) mRNA level. Entpd1 ${ }^{+/+}$: wild type mice. Entpd1 ${ }^{-/-}$: NTPDase1 deficient mice. Data presented are the means \pm SEM of three independent experiments in duplicate each with SMCs pooled from three mice. 


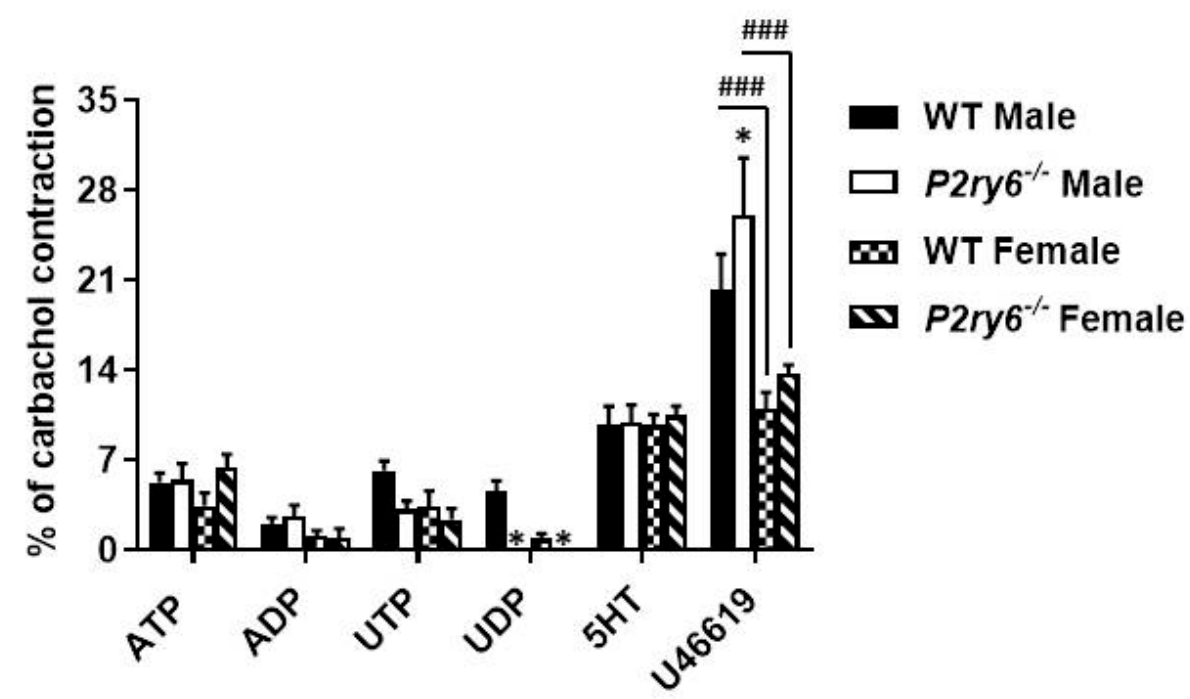

Figure 6. Contractile effect of extracellular nucleotides on male and female strips from $P 2 r y 6^{-/-}$ mouse bladders. Data are presented as the mean \pm SEM of 15 contraction experiments with strips from WT (wild type) and $P 2 r y 6^{-/-}\left(\mathrm{P} \mathrm{Y}_{6}\right.$ receptor knock-out) male bladders and 10 with strips from WT and $P 2 r y 6^{-/-}$female bladders. One symbol $p<0.05,3$ symbols $p<0.001$. ${ }^{*}$ Contraction of $P 2 r y 6^{-/-}$bladders compared to WT; \# Contraction of male strips compared to female strips of the same genotype. ATP, ADP, UTP, and UDP were used at the concentration of $100 \mu \mathrm{M}, 5 \mathrm{HT}$ at $10 \mu \mathrm{M}$, and $\mathrm{U} 46619$ at $100 \mathrm{nM}$.

\subsection{Apyrase Reversed the Increased Contraction in Entpd1 ${ }^{-/}$Bladders}

To confirm the role of NTPDase1 nucleotidase activity in the contraction process, we used $2 \mathrm{U} / \mathrm{mL}$ of potato apyrase, a commercially available enzyme that hydrolyses nucleotides similarly as does NTPDase1. As can be seen in Figure 7A, responses to ATP, ADP, UTP, and UDP were significantly reduced in Entpd1 ${ }^{-/-}$bladders in presence of apyrase. Heat inactivated apyrase did not have any effects on nucleotide induced contraction in either Entpd1 $1^{+/+}$or Entpd1 $1^{-/-}$bladders (Figure 7B), confirming that its effect was due to nucleotidase activity. 


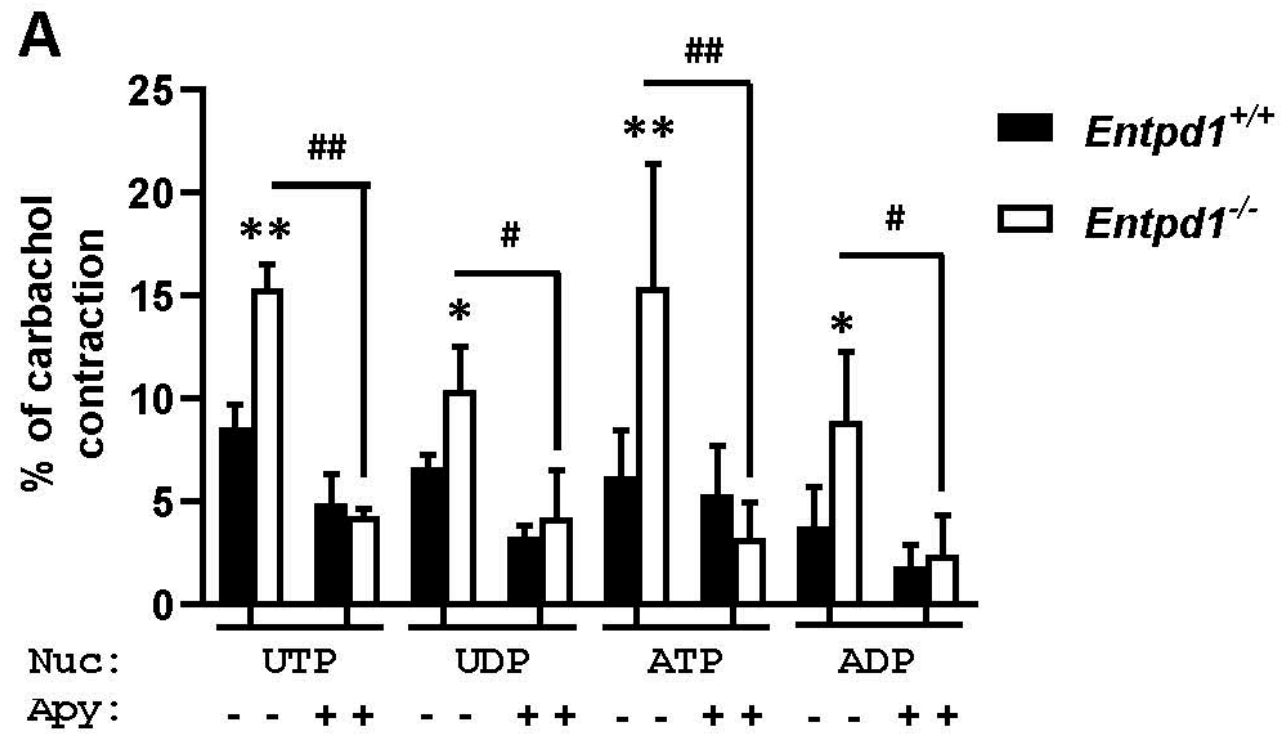

B

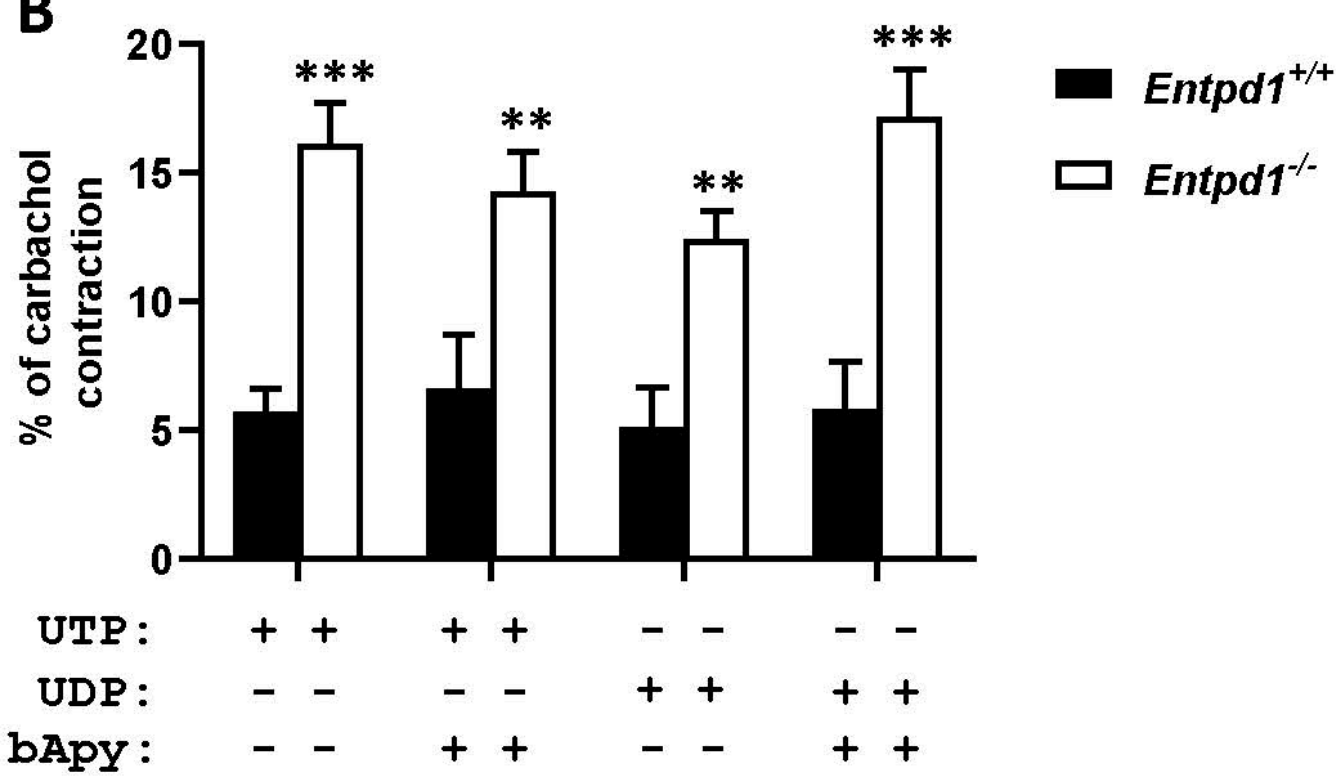

Figure 7. Effect of apyrase (Apy, $2 \mathrm{U} / \mathrm{mL})(\mathrm{A})$ and the same amount of boiled apyrase (bApy) (B) on contraction induced by $100 \mu \mathrm{M}$ ATP, ADP, UTP, or UDP on strips from male mouse bladders. Data presented are the mean \pm SEM of four contraction experiments with strips from different mice. One symbol $p<0.05$, two symbols $p<0.01$, and three symbols $p<0.001$. ${ }^{*}$ Contraction in Entpd1 $1^{-/-}$bladders compared to contraction in WT; \# Contraction in Entpd1 ${ }^{-/-}$bladders without apyrase compared to Entpd1 ${ }^{-/-}$bladders in presence of apyrase. There was no significant difference for WT bladders in presence or absence of apyrase or boiled apyrase.

\section{Discussion}

Over the past decades, NTPDase1 was reported to regulate several vascular functions such as thrombosis [30], angiogenesis [43], and vascular permeability [44]. In this study, we show that NTPDase1 was localized at the surface of bladder SMCs as demonstrated by immunohistochemistry (Figure 1). This localization correlated with high hydrolytic activity detected in wild type SMCs for ATP, ADP, UTP, and UDP which was absent at the surface of Entpd1 $1^{-/-}$bladder (Figure 2). Accordingly, specific activity in tissue homogenates was reduced in Entpd1 ${ }^{-/-}$bladder (Figure 3). Therefore, our results presented in this work 
demonstrate that NTPDase1 is the dominant ectonucleotidase in bladder SMCs in agreement with a previous study which reported NTPDase1 labeling by immunofluorescence in detrusor smooth muscle cells of mice bladder [45].

In absence of NTPDase1, we observed an enhanced contraction of bladder strips ex vivo (Figure 4). These nucleotide-dependent contractile effects appeared to be due to the activation of different receptors at the SMC surface. Based on our qPCR data, we found that $\mathrm{P}_{2} \mathrm{Y}_{6}, \mathrm{P}_{2} \mathrm{Y}_{1}$, and $\mathrm{P} 2 \mathrm{X} 1$ were the major receptors expressed at the mRNA levels. $\mathrm{P} 2 \mathrm{Y}_{12}$, $\mathrm{P}_{2} \mathrm{Y}_{2}$, and $\mathrm{P}_{2} \mathrm{Y}_{4}$ were also expressed at high levels (Figure 6). We also noted expression of, in decreasing order of expression, P2X7, P2X6, P2X4, P2X3, and P2X2 receptors which are potential candidates implicated in the contraction induced by ATP.

In the settings presented in this work, the strips from male bladders responded more strongly to UDP and UTP than to ADP and ATP, suggesting the implication of $\mathrm{P}^{2} \mathrm{Y}_{6}$ receptors (Figure 4). Experiments conducted with $P 2 r y 6^{-/-}$bladders confirmed the implication of this receptor in the contraction process (Figure 5) as the contractile effect of the $\mathrm{P} \mathrm{Y}_{6}$ agonist UDP was totally abrogated. This response was reduced in female bladder while ATP and ADP-induced contractions were comparable between bladders of both sexes. This suggests a differential sex-regulated contribution of $\mathrm{P}_{2} \mathrm{Y}_{6}$, versus the other $\mathrm{P} 2$ receptor types (e.g., $\mathrm{P}_{2} \mathrm{Y}_{12}$ and $\mathrm{P} 2 \mathrm{X} 1$ ) also involved in SMC contraction in bladder, between male and females.

We found that apyrase reversed the response observed in Entpd1 $1^{-/}$bladder (Figure 7A). This result confirmed that nucleotides induced contraction via the activation of P2 receptors and it also confirmed the role of NTPDase1 biochemical activity in the modulation of contraction.

The implication of $\mathrm{P}^{2} \mathrm{Y}_{6}$ in the contraction process has also been reported in vascular smooth muscles. Kauffenstein et al. (2010) reported an enhanced UTP and UDP dependent contraction in Entpd1 $1^{-/-}$mice aorta and mesenteric resistance arteries via $\mathrm{P}_{2} \mathrm{Y}_{6}$ receptors [19,46]. Yu et al. (2013) demonstrated that the absence of NTPDase1 led to an increased $\mathrm{P} \mathrm{Y}_{6}$ contractility of mice bladder smooth muscle upon activation with either UDP or MRS 2693, two specific agonists of this receptor [47]. This was confirmed by the fact that when cholinergic component was blocked with atropine, MRS 2693 significantly increased electric field stimulation induced purinergic contraction force up to $45 \%$. This potentiation was blunted by MRS 2578, a specific $\mathrm{P}_{2} \mathrm{Y}_{6}$ receptor antagonist. Carneiro et al. (2014) reported that the activation of $\mathrm{P}_{2} \mathrm{Y}_{6}$ receptors following instillation of UDP or PSB0474, another $\mathrm{P}_{2} \mathrm{Y}_{6}$ receptor agonist, into the bladder of anesthetized rats, increased the voiding frequency by releasing ATP from the urothelium [48]. More recently, Kira et al. showed that P2Y 6 receptor deficiency increased micturition frequency and attenuated sustained mice bladder contractility [49]. Hence, $\mathrm{P}_{2} \mathrm{Y}_{6}$ enhance bladder contraction through direct and indirect (P2X signaling) mechanisms. Difference in the activation of $\mathrm{P} \mathrm{Y}_{6}$ receptor due to sex was not investigated in these studies.

$\mathrm{P}_{2} \mathrm{Y}_{2}$ and /or P2Y $\mathrm{Y}_{4}$ were also implicated as UTP response was not completely abrogated in $P 2 r y 6^{-/-}$bladders. The response obtained with ADP in this study agrees with what was observed by Yu et al. (2014) who reported that ADP induced contraction in mice via $\mathrm{P}_{2} \mathrm{Y}_{12}$ receptors [50]. As high expression of the ADP receptor $\mathrm{P}_{2} \mathrm{Y}_{1}$ was also found by qPCR (Figure 6B), the role of this receptor in SMC contraction could also be possible.

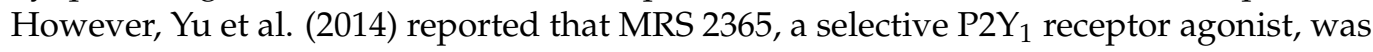
ineffective at eliciting bladder SMCs contraction [50]. This was corroborated with MRS 2500, a selective P2 $Y_{1}$ receptor antagonist, which did not inhibit ADP-induced bladder SMCs contraction. They concluded that $\mathrm{P}_{2} \mathrm{Y}_{1}$ receptor was not implicated in bladder contraction.

Bladder contractility elicited by ATP has been described for nearly 50 years [51,52]. ATP-induced contraction reported in this study is in line with other studies which have reported that this contractile effect was due to P2X1 receptor activation [53,54]. We also found that other P2X receptors were expressed in the bladder (Figure $6 \mathrm{C}$ ) and our results do not exclude that these receptors could also participate in the contraction. In agreement, 
Kennedy et al. suggested the implication of P2X1/P2X4 heteromultimer in the contraction of mice and guinea pig bladders [55]. This result was, however, in disagreement with the conclusion of Yu et al. who localized P2X4 receptor by immunofluorescence between muscle bundles and associated with the vasculature [56]. They also showed that P2X4 null mice maintained macroscopic and voiding function similarities with wild type mice [56]. Altogether, these data suggest that P2X1 receptor is the main P2X subtype implicated in ATP-induced bladder contractility and they suggest that other P2X subtypes might play a role in other bladder functions.

The increase in the contractile response to nucleotides in Entpd1 ${ }^{-/}$- bladder reveals a crucial role for NTPDase1 nucleotidase activity to prevent nucleotide receptors activation. This increased nucleotide contractility in Entpd1 $1^{-/-}$bladder is in line with the previous report of Kauffenstein et al. (2010) in the vasculature [19]. Other studies with Entpd1 ${ }^{-/-}$ mice have however revealed P2 receptors desensitization, suggesting that NTPDase1 can also prevent desensitization and can therefore allow some P2 receptor activation in the appropriate time $[30,43,57,58]$. Thus, depending on the type of receptors involved, NTPDase1 may play different roles: for easily desensitized receptors such as $\mathrm{P}_{2} \mathrm{Y}_{1}$ and P2X1, NTPDase1 can prevent receptor desensitization. In contrast, for poorly desensitized receptors such as $\mathrm{P}_{2} \mathrm{Y}_{6}$, as evidenced here and by Kauffenstein et al. (2010), NTPDase1 limits their activation and its inhibition/deletion reveals full contractile effects of the latter receptor. NTPDase1 appears therefore as essential in terminating $\mathrm{P}_{2} \mathrm{Y}_{6}$ receptor signaling, especially considering the few uracil nucleotides metabolizing enzymes apart from NTPDases [25].

Taken together, our data suggest that NTPDase1 modulates mouse bladder SMCs contraction by regulating the activation of several nucleotide receptors.

A peculiar finding made during this study was the decrease in UTP and UDP responses in female bladder compared to male bladder. This indicates sex difference in mice bladder smooth muscle contraction in response to stimulating nucleotides. We suspected a reduced expression of $\mathrm{P}_{2} \mathrm{Y}_{6}$ in female bladders. This was however not confirmed in our RT-qPCR results for P2Y receptors (Figure 6B). It is likely that despite similar mRNA levels, protein expression of $\mathrm{P}_{2} \mathrm{Y}_{6}$ or coupling to intracellular signaling pathways may differ from male to female. Notably, $\mathrm{P}_{2} \mathrm{Y}_{6}$ and thromboxane A2 receptors share Rho signaling pathway components $[46,59,60]$. Sex differences in this pathway may explain both UTP/UDP and U46619 (thromboxane analogue) enhanced contraction in male bladder.

Such difference in response to stimulating molecules between sexes has been extensively demonstrated in vascular functions of the aorta, coronary, mesenteric, and renal arteries from various species including mice, rat, and pigs [61-63]. The reduced response to UTP and UDP (Figure 4) correlates with the results of Ma et al. who found a reduction in the contraction of SMCs of female rat aorta stimulated by phenylephrine, angiotensin, and depolarizing $\mathrm{KCl}$ in comparison to male aorta [64]. They associated this reduction to an increased estrogen receptor expression in the female tissue.

More recently, Caiazzo et al. found a reduced in vitro response to ADP of female rat's platelets compared to male platelets and concluded that this was due to an increased expression and activity of NTPDase1 [65]. Conversely, ecto-5'-nucleotidase expression did not follow the same pattern as comparable expression levels were found between male and female platelets [65]. This last enzyme was reported to control extracellular adenosine level in a murine model over-expressing NTPDase1, thereby, reducing ex vivo platelet aggregation and exerting antithrombotic, anti-inflammatory, and cardio protective effects through adenosine receptors signaling [66,67].

Regarding bladder function, sex differences in the pharmacology and physiology of lower urinary tract has been investigated at the neurogenic level and has been mainly attributed to differential expression of muscarinic and adrenergic receptors between male and female in humans, mice, rats, and rabbits [68]. Kamei et al. investigated how sex and age affects bladder function and gene expression in mice. They reported storage and voiding dysfunctions with ageing in both sexes. They also pointed out weaker detrusor 
strips contractile response from aged mice, decreased mRNA expression of bladder tissue for M3 muscarinic receptors in aged males and $\beta 2$-adrenoreceptors in aged females. They concluded that these age-related impairments were generally more severe in males [69].

Altogether, these data show that bladder contractility obeys different rules in males and in females. In addition, our data suggest that NTPDase1 and $\mathrm{P}_{2} \mathrm{Y}_{6}$ receptor signaling contribute to these differences.

In this work, we focused our attention on nucleotide signaling in the activation of contraction. The role of adenosine, which has been shown to inhibit human and mice bladder SMCs contractility [70,71] was not investigated in this work. Nevertheless, our work suggests the potential contribution of ecto-5'-nucleotidase in these effects. Indeed, we have demonstrated the presence of ecto- $5^{\prime}$-nucleotidase, alongside NTPDase1, by immunohistochemistry, by enzymatic histochemistry, and by RT-qPCR (Figure 6D). We have also shown the expression of adenosine receptors by RT-qPCR (Figure 6E). It is worth remembering that NTPDase1 not only terminates nucleoside triphosphate signaling but also generates AMP, which is subsequently converted to adenosine by ecto- $5^{\prime}$-nucleotidase, which can finally activate P1 receptors and modulate bladder SMCs contraction or dilation.

\section{Conclusions}

In this work, we have shown that NTPDase1 is the major ectonucleotidase hydrolyzing nucleotides at the surface of male and female mice bladder SMCs where it reduced nucleotide-induced contraction by regulating their concentration levels. In absence of NTPDase1 in Entpd1 $1^{-/}$bladder, an increased contraction was observed in response to stimulating nucleotides. The nucleotide receptor $\mathrm{P}_{2} \mathrm{Y}_{6}$ was the most important nucleotide receptor in these effects in male. Interestingly, the $\mathrm{P}_{2} \mathrm{Y}_{6}$-dependent constrictor response was significantly reduced in female Entpd $1^{-/-}$bladder when compared to male. $\mathrm{P}_{2} \mathrm{Y}_{6}, \mathrm{P}_{2} \mathrm{Y}_{1}$, and P2X1 were the most abundantly expressed $\mathrm{P} 2$ receptors at the mRNA level, followed by several other P2 receptors, among which $\mathrm{P}_{2} \mathrm{Y}_{12}, \mathrm{P}_{2} \mathrm{Y}_{2}, \mathrm{P}_{2} \mathrm{Y}_{4}$, which also appeared to contribute to SMCs contraction. The increased contractions observed in Entpd1 $1^{-/-}$bladders were reversed by potato apyrase, confirming the implication of NTPDase1 biochemical activity in the regulation of nucleotide-dependent constrictor effects. The results presented in this study suggest that changes in NTPDase1 enzymatic activity due to pathological conditions like lower urinary tract symptoms could contribute to bladder contraction disorders.

Author Contributions: R.B.B.K. participated in the design of the study, performed all experiments, drafted the manuscript, and analyzed the data. G.K. initiated this study and obtained the preliminary data that lead to this project. J.P. was responsible for colony maintenance and provided help with mouse tissue activity experiments. B.R. provided $\mathrm{P}_{2} \mathrm{Y}_{6}$ deficient mice. J.S. supervised the work. All authors participated in the redaction of the manuscript. All authors have read and agreed to the published version of the manuscript.

Funding: This work was supported by grants to J.S. from the Natural Sciences and Engineering Research Council of Canada (RGPIN-2016-05867). R.B.B.K. was a recipient of a Studentship from Université Laval and J.S. of a "Chercheur National" Scholarship award from the Fonds de Recherche du Québec-Santé (FRQS).

Informed Consent Statement: Not required.

Data Availability Statement: All data supporting reported results in this study are included in the manuscript or uploaded as Figures Zip file during the submission.

Conflicts of Interest: The authors declare no financial or commercial conflict of interest.

\section{Abbreviations}




$\begin{array}{ll}\text { SMC } & \text { Smooth muscle cell } \\ \text { ATP } & \text { Adenosine 5'-triphosphate } \\ \text { ADP } & \text { Adenosine 5'-diphosphate } \\ \text { UTP } & \text { Uridine 5'-triphosphate } \\ \text { UDP } & \text { Uridine 5'-diphosphate } \\ \text { AMP } & \text { Adenosine 5'-monophosphate } \\ \text { UMP } & \text { Uridine 5'-monophosphate } \\ \text { RT-qPCR } & \text { Quantitative Real time polymerase chain reaction } \\ \text { E-NTPDase } & \text { Ecto-nucleoside triphosphate diphosphohydrolase } \\ \text { OCT } & \text { Optimal cutting temperature } \\ \text { Pi } & \text { Inorganic phosphate } \\ \text { SEM } & \text { Standard error of mean } \\ \text { 5HT } & \text { 5-hydroxytryptamine } \\ \text { U46619 } & \text { Thromboxane A2 analogue } \\ \text { GAPDH } & \text { Glyceraldehyde 3-phosphate dehydrogenase } \\ \text { ACTB } & \text { Actin beta }\end{array}$

\section{References}

1. Vassort, G. Adenosine 5'-triphosphate: A P2-purinergic agonist in the myocardium. Physiol. Rev. 2001, 81, 767-806. [CrossRef] [PubMed]

2. Kukulski, F.; Levesque, S.A.; Sevigny, J. Impact of ectoenzymes on p2 and p1 receptor signaling. Adv. Pharmacol. 2011, 61, 263-299. [CrossRef] [PubMed]

3. Yegutkin, G.G. Nucleotide- and nucleoside-converting ectoenzymes: Important modulators of purinergic signalling cascade. Biochim. Biophys. Acta 2008, 1783, 673-694. [CrossRef] [PubMed]

4. Abbracchio, M.P.; Burnstock, G.; Boeynaems, J.M.; Barnard, E.A.; Boyer, J.L.; Kennedy, C.; Knight, G.E.; Fumagalli, M.; Gachet, C.; Jacobson, K.A.; et al. International Union of Pharmacology LVIII: Update on the P2Y G protein-coupled nucleotide receptors: From molecular mechanisms and pathophysiology to therapy. Pharmacol. Rev. 2006, 58, 281-341. [CrossRef] [PubMed]

5. $\quad$ Chen, Y.; Corriden, R.; Inoue, Y.; Yip, L.; Hashiguchi, N.; Zinkernagel, A.; Nizet, V.; Insel, P.A.; Junger, W.G. ATP release guides neutrophil chemotaxis via P2Y2 and A3 receptors. Science 2006, 314, 1792-1795. [CrossRef] [PubMed]

6. Lazarowski, E.R.; Boucher, R.C.; Harden, T.K. Mechanisms of release of nucleotides and integration of their action as P2X- and P2Y-receptor activating molecules. Mol. Pharmacol. 2003, 64, 785-795. [CrossRef]

7. $\quad$ Eltzschig, H.K.; Eckle, T.; Mager, A.; Kuper, N.; Karcher, C.; Weissmuller, T.; Boengler, K.; Schulz, R.; Robson, S.C.; Colgan, S.P. ATP release from activated neutrophils occurs via connexin 43 and modulates adenosine-dependent endothelial cell function. Circ. Res. 2006, 99, 1100-1108. [CrossRef]

8. Woehrle, T.; Yip, L.; Elkhal, A.; Sumi, Y.; Chen, Y.; Yao, Y.; Insel, P.A.; Junger, W.G. Pannexin-1 hemichannel-mediated ATP release together with P2X1 and P2X4 receptors regulate T-cell activation at the immune synapse. Blood 2010, 116, 3475-3484. [CrossRef]

9. Kukulski, F.; Bahrami, F.; Ben Yebdri, F.; Lecka, J.; Martín-Satué, M.; Lévesque, S.A.; Sévigny, J. NTPDase1 controls IL-8 production by buman neutrophils. J. Immunol. 2011, 187, 644-653. [CrossRef]

10. Corriden, R.; Insel, P.A. Basal release of ATP: An autocrine-paracrine mechanism for cell regulation. Sci. Signal. 2010, 3, re1. [CrossRef]

11. Katsuragi, T.; Tokunaga, T.; Ogawa, S.; Soejima, O.; Sato, C.; Furukawa, T. Existence of ATP-evoked ATP release system in smooth muscles. J. Pharmacol. Exp. Ther. 1991, 259, 513-518. [PubMed]

12. Bergfeld, G.R.; Forrester, T. Release of ATP from human erythrocytes in response to a brief period of hypoxia and hypercapnia. Cardiovasc. Res. 1992, 26, 40-47. [CrossRef] [PubMed]

13. Bodin, P.; Burnstock, G. Synergistic effect of acute hypoxia on flow-induced release of ATP from cultured endothelial cells. Experientia 1995, 51, 256-259. [CrossRef] [PubMed]

14. Burnstock, G. Purine and purinergic receptors. Brain Neurosci. Adv. 2018, 2. [CrossRef]

15. Ciruela, F.; Jacobson, K.A. Editorial: Purinergic Pharmacology. Front. Pharmacol. 2019, 10, 21. [CrossRef]

16. Von Kugelgen, I.; Wetter, A. Molecular pharmacology of P2Y-receptors. Naunyn Schmiedebergs Arch. Pharmacol. 2000, 362, 310-323. [CrossRef]

17. Von Kugelgen, I.; Harden, T.K. Molecular pharmacology, physiology, and structure of the P2Y receptors. Adv. Pharmacol. 2011, 61,373-415. [CrossRef]

18. Jacobson, K.A.; Paoletta, S.; Katritch, V.; Wu, B.; Gao, Z.G.; Zhao, Q.; Stevens, R.C.; Kiselev, E. Nucleotides Acting at P2Y Receptors: Connecting Structure and Function. Mol. Pharmacol. 2015, 88, 220-230. [CrossRef]

19. Kauffenstein, G.; Drouin, A.; Thorin-Trescases, N.; Bachelard, H.; Robaye, B.; D'Orleans-Juste, P.; Marceau, F.; Thorin, E.; Sevigny, J. NTPDase1 (CD39) controls nucleotide-dependent vasoconstriction in mouse. Cardiovasc. Res. 2010, 85, 204-213. [CrossRef]

20. Bours, M.J.; Swennen, E.L.; Di Virgilio, F.; Cronstein, B.N.; Dagnelie, P.C. Adenosine 5' -triphosphate and adenosine as endogenous signaling molecules in immunity and inflammation. Pharmacol. Ther. 2006, 112, 358-404. [CrossRef]

21. Ralevic, V.; Burnstock, G. Receptors for purines and pyrimidines. Pharmacol. Rev. 1998, 50, 413-492. 
22. Erlinge, D.; Burnstock, G. P2 receptors in cardiovascular regulation and disease. Purinergic. Signal. 2008, 4, 1-20. [CrossRef]

23. Gitterman, D.P.; Evans, R.J. Properties of P2X and P2Y receptors are dependent on artery diameter in the rat mesenteric bed. Br. J. Pharmacol. 2000, 131, 1561-1568. [CrossRef]

24. Shryock, J.C.; Belardinelli, L. Adenosine and adenosine receptors in the cardiovascular system: Biochemistry, physiology, and pharmacology. Am. J. Cardiol. 1997, 79, 2-10. [CrossRef]

25. Robson, S.C.; Sevigny, J.; Zimmermann, H. The E-NTPDase family of ectonucleotidases: Structure function relationships and pathophysiological significance. Purinergic Signal. 2006, 2, 409-430. [CrossRef]

26. Kukulski, F.; Levesque, S.A.; Lavoie, E.G.; Lecka, J.; Bigonnesse, F.; Knowles, A.F.; Robson, S.C.; Kirley, T.L.; Sevigny, J. Comparative hydrolysis of P2 receptor agonists by NTPDases 1, 2, 3 and 8. Purinergic Signal. 2005, 1, 193-204. [CrossRef]

27. Colgan, S.P.; Eltzschig, H.K.; Eckle, T.; Thompson, L.F. Physiological roles for ecto-5' ${ }^{\prime}$-nucleotidase (CD73). Purinergic Signal. 2006, 2, 351-360. [CrossRef]

28. Vorhoff, T.; Zimmermann, H.; Pelletier, J.; Sevigny, J.; Braun, N. Cloning and characterization of the ecto-nucleotidase NTPDase3 from rat brain: Predicted secondary structure and relation to other members of the E-NTPDase family and actin. Purinergic Signal. 2005, 1, 259-270. [CrossRef]

29. Sevigny, J.; Sundberg, C.; Braun, N.; Guckelberger, O.; Csizmadia, E.; Qawi, I.; Imai, M.; Zimmermann, H.; Robson, S.C. Differential catalytic properties and vascular topography of murine nucleoside triphosphate diphosphohydrolase 1 (NTPDase1) and NTPDase2 have implications for thromboregulation. Blood 2002, 99, 2801-2809. [CrossRef]

30. Enjyoji, K.; Sevigny, J.; Lin, Y.; Frenette, P.S.; Christie, P.D.; Esch, J.S., II; Imai, M.; Edelberg, J.M.; Rayburn, H.; Lech, M.; et al. Targeted disruption of cd39/ATP diphosphohydrolase results in disordered hemostasis and thromboregulation. Nat. Med. 1999, 5, 1010-1017. [CrossRef]

31. Lavoie, E.G.; Gulbransen, B.D.; Martin-Satue, M.; Aliagas, E.; Sharkey, K.A.; Sevigny, J. Ectonucleotidases in the digestive system: Focus on NTPDase3 localization. Am. J. Physiol. Gastrointest. Liver Physiol. 2011, 300, G608-G620. [CrossRef]

32. Kauffenstein, G.; Pelletier, J.; Lavoie, E.G.; Kukulski, F.; Martin-Satue, M.; Dufresne, S.S.; Frenette, J.; Ribas Furstenau, C.; Sereda, M.J.; Toutain, B.; et al. Nucleoside triphosphate diphosphohydrolase-1 ectonucleotidase is required for normal vas deferens contraction and male fertility through maintaining P2X1 receptor function. J. Biol. Chem. 2014, 289, 28629-28639. [CrossRef]

33. Martin-Satue, M.; Lavoie, E.G.; Pelletier, J.; Fausther, M.; Csizmadia, E.; Guckelberger, O.; Robson, S.C.; Sevigny, J. Localization of plasma membrane bound NTPDases in the murine reproductive tract. Histochem. Cell Biol. 2009, 131, 615-628. [CrossRef]

34. Bartel, D.L.; Sullivan, S.L.; Lavoie, E.G.; Sevigny, J.; Finger, T.E. Nucleoside triphosphate diphosphohydrolase-2 is the ecto-ATPase of type I cells in taste buds. J. Comp. Neurol. 2006, 497, 1-12. [CrossRef]

35. Pelletier, J.; Salem, M.; Lecka, J.; Fausther, M.; Bigonnesse, F.; Sevigny, J. Generation and Characterization of Specific Antibodies to the Murine and Human Ectonucleotidase NTPDase8. Front. Pharmacol. 2017, 8, 115. [CrossRef]

36. Fausther, M.; Lecka, J.; Soliman, E.; Kauffenstein, G.; Pelletier, J.; Sheung, N.; Dranoff, J.A.; Sevigny, J. Coexpression of ecto$5^{\prime}$-nucleotidase/CD73 with specific NTPDases differentially regulates adenosine formation in the rat liver. Am. J. Physiol. Gastrointest. Liver Physiol. 2012, 302, G447-G459. [CrossRef]

37. Bar, I.; Guns, P.J.; Metallo, J.; Cammarata, D.; Wilkin, F.; Boeynams, J.M.; Bult, H.; Robaye, B. Knockout mice reveal a role for P2Y6 receptor in macrophages, endothelial cells, and vascular smooth muscle cells. Mol. Pharmacol. 2008, 74, 777-784. [CrossRef]

38. Braun, N.; Sevigny, J.; Mishra, S.K.; Robson, S.C.; Barth, S.W.; Gerstberger, R.; Hammer, K.; Zimmermann, H. Expression of the ecto-ATPase NTPDase2 in the germinal zones of the developing and adult rat brain. Eur. J. Neurosci. 2003, 17, 1355-1364. [CrossRef]

39. Sevigny, J.; Levesque, F.P.; Grondin, G.; Beaudoin, A.R. Purification of the blood vessel ATP diphosphohydrolase, identification and localisation by immunological techniques. Biochim. Biophys. Acta 1997, 1334, 73-88. [CrossRef]

40. Baykov, A.A.; Evtushenko, O.A.; Avaeva, S.M. A malachite green procedure for orthophosphate determination and its use in alkaline phosphatase-based enzyme immunoassay. Anal. Biochem. 1988, 171, 266-270. [CrossRef]

41. Lu, M.; Zhu, K.; Schulam, P.G.; Chai, T.C. A non-enzymatic method for dissection of mouse bladder urothelial tissue. Nat. Protoc. 2019, 14, 1280-1292. [CrossRef]

42. Heine, P.; Braun, N.; Heilbronn, A.; Zimmermann, H. Functional characterization of rat ecto-ATPase and ecto-ATP diphosphohydrolase after heterologous expression in CHO cells. Eur. J. Biochem. 1999, 262, 102-107. [CrossRef]

43. Goepfert, C.; Sundberg, C.; Sevigny, J.; Enjyoji, K.; Hoshi, T.; Csizmadia, E.; Robson, S. Disordered cellular migration and angiogenesis in cd39-null mice. Circulation 2001, 104, 3109-3115. [CrossRef]

44. Guckelberger, O.; Sun, X.F.; Sevigny, J.; Imai, M.; Kaczmarek, E.; Enjyoji, K.; Kruskal, J.B.; Robson, S.C. Beneficial effects of CD39/ecto-nucleoside triphosphate diphosphohydrolase-1 in murine intestinal ischemia-reperfusion injury. Thromb. Haemost. 2004, 91, 576-586. [CrossRef]

45. Yu, W.; Robson, S.C.; Hill, W.G. Expression and distribution of ectonucleotidases in mouse urinary bladder. PLoS ONE 2011, 6, e18704. [CrossRef]

46. Kauffenstein, G.; Tamareille, S.; Prunier, F.; Roy, C.; Ayer, A.; Toutain, B.; Billaud, M.; Isakson, B.E.; Grimaud, L.; Loufrani, L.; et al. Central Role of P2Y6 UDP Receptor in Arteriolar Myogenic Tone. Arterioscler. Thromb. Vasc. Biol. 2016, 36, 1598-1606. [CrossRef]

47. Yu, W.; Sun, X.; Robson, S.C.; Hill, W.G. Extracellular UDP enhances P2X-mediated bladder smooth muscle contractility via P2Y(6) activation of the phospholipase C/inositol trisphosphate pathway. FASEB J. 2013, 27, 1895-1903. [CrossRef] 
48. Carneiro, I.; Timoteo, M.A.; Silva, I.; Vieira, C.; Baldaia, C.; Ferreirinha, F.; Silva-Ramos, M.; Correia-de-Sa, P. Activation of P2Y6 receptors increases the voiding frequency in anaesthetized rats by releasing ATP from the bladder urothelium. Br. J. Pharmacol. 2014, 171, 3404-3419. [CrossRef]

49. Kira, S.; Yoshiyama, M.; Tsuchiya, S.; Shigetomi, E.; Miyamoto, T.; Nakagomi, H.; Shibata, K.; Mochizuki, T.; Takeda, M.; Koizumi, S. P2Y6-deficiency increases micturition frequency and attenuates sustained contractility of the urinary bladder in mice. Sci. Rep. 2017, 7, 771. [CrossRef]

50. Yu, W.; Sun, X.; Robson, S.C.; Hill, W.G. ADP-induced bladder contractility is mediated by P2Y12 receptor and temporally regulated by ectonucleotidases and adenosine signaling. FASEB J. 2014, 28, 5288-5298. [CrossRef]

51. Burnstock, G.; Dumsday, B.; Smythe, A. Atropine resistant excitation of the urinary bladder: The possibility of transmission via nerves releasing a purine nucleotide. Br. J. Pharmacol. 1972, 44, 451-461. [CrossRef] [PubMed]

52. Burnstock, G.; Satchell, D.G.; Smythe, A. A comparison of the excitatory and inhibitory effects of non-adrenergic, non-cholinergic nerve stimulation and exogenously applied ATP on a variety of smooth muscle preparations from different vertebrate species. Br. J. Pharmacol. 1972, 46, 234-242. [CrossRef] [PubMed]

53. Vial, C.; Evans, R.J. P2X receptor expression in mouse urinary bladder and the requirement of P2X(1) receptors for functional P2X receptor responses in the mouse urinary bladder smooth muscle. Br. J. Pharmacol. 2000, 131, 1489-1495. [CrossRef] [PubMed]

54. Heppner, T.J.; Werner, M.E.; Nausch, B.; Vial, C.; Evans, R.J.; Nelson, M.T. Nerve-evoked purinergic signalling suppresses action potentials, $\mathrm{Ca} 2+$ flashes and contractility evoked by muscarinic receptor activation in mouse urinary bladder smooth muscle. $J$. Physiol. 2009, 587, 5275-5288. [CrossRef] [PubMed]

55. Kennedy, C.; Tasker, P.N.; Gallacher, G.; Westfall, T.D. Identification of atropine- and P2X1 receptor antagonist-resistant, neurogenic contractions of the urinary bladder. J. Neurosci. 2007, 27, 845-851. [CrossRef] [PubMed]

56. Yu, W.; Hill, W.G.; Robson, S.C.; Zeidel, M.L. Role of P2X4 Receptor in Mouse Voiding Function. Sci. Rep. 2018, 8, 1838. [CrossRef] [PubMed]

57. Schaefer, U.; Machida, T.; Broekman, M.J.; Marcus, A.J.; Levi, R. Targeted deletion of ectonucleoside triphosphate diphosphohydrolase 1/CD39 leads to desensitization of pre- and postsynaptic purinergic P2 receptors. J. Pharmacol. Exp. Ther. 2007, 322, 1269-1277. [CrossRef]

58. Mizumoto, N.; Kumamoto, T.; Robson, S.C.; Sevigny, J.; Matsue, H.; Enjyoji, K.; Takashima, A. CD39 is the dominant Langerhans cell-associated ecto-NTPDase: Modulatory roles in inflammation and immune responsiveness. Nat. Med. 2002, 8, 358-365. [CrossRef]

59. Song, P.; Zhang, M.; Wang, S.; Xu, J.; Choi, H.C.; Zou, M.H. Thromboxane A2 receptor activates a Rho-associated kinase/LKB1/PTEN pathway to attenuate endothelium insulin signaling. J. Biol. Chem. 2009, 284, 17120-17128. [CrossRef]

60. Goulopoulou, S.; Hannan, J.L.; Matsumoto, T.; Webb, R.C. Pregnancy reduces RhoA/Rho kinase and protein kinase C signaling pathways downstream of thromboxane receptor activation in the rat uterine artery. Am. J. Physiol. Heart Circ. Physiol. 2012, 302, H2477-H2488. [CrossRef]

61. Matsumoto, T.; Kakami, M.; Kobayashi, T.; Kamata, K. Gender differences in vascular reactivity to endothelin-1 (1-31) in mesenteric arteries from diabetic mice. Peptides 2008, 29, 1338-1346. [CrossRef] [PubMed]

62. Murphy, J.G.; Khalil, R.A. Gender-specific reduction in contractility and $[\mathrm{Ca}(2+)](\mathrm{i})$ in vascular smooth muscle cells of female rat. Am. J. Physiol. Cell Physiol. 2000, 278, C834-C844. [CrossRef] [PubMed]

63. Barber, D.A.; Miller, V.M. Gender differences in endothelium-dependent relaxations do not involve NO in porcine coronary arteries. Am. J. Physiol. 1997, 273, H2325-H2332. [CrossRef] [PubMed]

64. Ma, Y.; Qiao, X.; Falone, A.E.; Reslan, O.M.; Sheppard, S.J.; Khalil, R.A. Gender-specific reduction in contraction is associated with increased estrogen receptor expression in single vascular smooth muscle cells of female rat. Cell Physiol. Biochem. 2010, 26, 457-470. [CrossRef]

65. Caiazzo, E.; Bilancia, R.; Rossi, A.; Ialenti, A.; Cicala, C. Ectonucleoside Triphosphate Diphosphohydrolase-1/CD39 Affects the Response to ADP of Female Rat Platelets. Front. Pharmacol. 2019, 10, 1689. [CrossRef]

66. Koziak, K.; Bojakowska, M.; Robson, S.C.; Bojakowski, K.; Soin, J.; Csizmadia, E.; Religa, P.; Gaciong, Z.; Kaczmarek, E. Overexpression of CD39/nucleoside triphosphate diphosphohydrolase-1 decreases smooth muscle cell proliferation and prevents neointima formation after angioplasty. J. Thromb. Haemost. 2008, 6, 1191-1197. [CrossRef]

67. Huttinger, Z.M.; Milks, M.W.; Nickoli, M.S.; Aurand, W.L.; Long, L.C.; Wheeler, D.G.; Dwyer, K.M.; d'Apice, A.J.; Robson, S.C.; Cowan, P.J.; et al. Ectonucleotide triphosphate diphosphohydrolase-1 (CD39) mediates resistance to occlusive arterial thrombus formation after vascular injury in mice. Am. J. Pathol. 2012, 181, 322-333. [CrossRef]

68. Patra, P.B.; Patra, S. Sex differences in the physiology and pharmacology of the lower urinary tract. Curr. Urol. 2013, 6, 179-188. [CrossRef]

69. Kamei, J.; Ito, H.; Aizawa, N.; Hotta, H.; Kojima, T.; Fujita, Y.; Ito, M.; Homma, Y.; Igawa, Y. Age-related changes in function and gene expression of the male and female mouse bladder. Sci. Rep. 2018, 8, 2089. [CrossRef]

70. Searl, T.J.; Dynda, D.I.; Alanee, S.R.; El-Zawahry, A.M.; McVary, K.T.; Silinsky, E.M. A1 Adenosine Receptor-Mediated Inhibition of Parasympathetic Neuromuscular Transmission in Human and Murine Urinary Bladder. J. Pharmacol. Exp. Ther. 2016, 356, 116-122. [CrossRef]

71. Hao, Y.; Wang, L.; Chen, H.; Hill, W.G.; Robson, S.C.; Zeidel, M.L.; Yu, W. Targetable purinergic receptors P2Y12 and A2b antagonistically regulate bladder function. JCI Insight 2019, 4. [CrossRef] [PubMed] 